\title{
Magmatic and Tectonic History of Iceland's Western Rift Zone at Lake Thingvallavatn
}

Jonathan M. Bull ${ }^{*}$

Timothy A. Minshull

School of Ocean and Earth Science, National Oceanography Centre, Southampton

University, Southampton SO14 3ZH, UK

Neil C. Mitchell

School of Earth, Ocean and Planetary Sciences, Cardiff University, PO Box 914,

Cardiff CF10 3YE, UK

Justin K. Dix

School of Ocean and Earth Science, National Oceanography Centre, Southampton

University, Southampton SO14 3ZH, UK

Jorunn Hardardottir

National Energy Authority (Orkustofnun), Hydrological Service, Reykjavik, Iceland

*To whom correspondence should be addressed. Email: bull@soton.ac.uk

\section{ABSTRACT}

High rates of Holocene sedimentation in a lake spanning the Thingvellir rift zone of western Iceland provide an unusual opportunity to study the interaction of tectonic and magmatic processes on timescales of thousands of years. Lake Thingvallavatn is oriented SW-NE, parallel to the trend of normal faults and fissures which extend northeast from Hengill, a central volcano system. Thingvallavatn's lake sediments provide a continuous high-fidelity record of tectono-magmatic processes. "Chirp” sub-bottom profiler and sidescan records, together with sediment core information, enabled the lake stratigraphy to be constrained well since the emplacement of a post-glacial lava at $9.1 \pm 0.3 \mathrm{ka}$. This lava, together with three younger horizons, enabled detailed study of the main tectonic and magmatic events. A major Hengill volcanic event which controlled the development of the present-day lake morphology occurred at 1.9 ka with the eruption of a scoria cone within the lake (Sandey). During this event, the Nesjahraun lava was erupted into the southern part of the lake, the Sandey scoria cone was formed, and major faulting and subsidence occurred in the northern part of the lake, resulting in the formation of an asymmetrical rift. Within the southern part of the lake, a deformed sequence of sediments of age 2.9 - $1.5 \mathrm{ka}$, between undeformed younger and older sediments, indicate that liquefaction phenomena are associated with the emplacement of the Nesjahraun lava. Analysis of fault displacement reveals that the total throw summed over all faults across the width of the rift zone is approximately constant $(110-130 \mathrm{~m})$ along the long axis of the rift. We estimate an extension rate on the faults of 3.3 $8.2 \mathrm{~mm} \mathrm{yr}^{-1}$ since $9.1 \mathrm{ka}$, assuming fault dips of $60-75^{\circ}$, which represents 17 - 
$43 \%$ of the total plate boundary extension estimated from global plate motion inversion. We speculate that the remaining extension must either be taken up elsewhere in Iceland, for example in the Eastern Rift Zone or along the South Island Seismic Zone, or that extension estimated over the last 9kyr underestimates the long-term extension rate due to incomplete sampling of the episodic magmatic component.

\section{Keywords: Neotectonics, Dikes, Subsidence, Normal faults, Iceland, Liquefaction}

\section{INTRODUCTION}

A current issue in studies of active rift zones is understanding the relationship between present-day geodetic/seismological measurements of strain, and longer-term data preserved in the geological record on timescales of millions of years. There is however little attention paid to the linkage between these timescales. Studies of processes on timescales of thousands of years bridge this gap and thus offer the opportunity to understand how tectonic and magmatic processes are partitioned and how the partitioning changes with time. Studies using high resolution marine seismic reflection profiles over a well-known stratigraphy have demonstrated how a continuous sedimentary record can be used to constrain tectonic and magmatic processes on timescales as short as a few thousand years (Taylor et al., 2004; Bull et al., 2003). Trenching studies provide higher temporal resolution, but lack extensive spatial coverage. An advantage of using marine seismic data is that both spatial and temporal variations in processes can be determined in a systematic manner. While there are examples of studies of sub-surface magmatic diking and associated surface faulting, graben formation and subsidence (e.g. Brandsdottir and Einarsson, 1979; Rubin, 1992; Cervelli et al., 2002; Pollard et al., 1983), determining the temporal development of a rift zone on timescales of thousands of years has not hitherto been possible due to the lack of chronological control.

Thingvallavatn (Fig. 1) is a lake situated within Iceland's western rift zone and was formed during deglaciation c. $10 \mathrm{ka} \mathrm{BP}$ when the inland ice retreated from the site. The lake sits $5 \mathrm{~km}$ north of the Hengill central volcano system that is the most active of three volcanic systems that form the Hengill Triple Junction (HTJ). The HTJ is situated at the intersection of the western rift zone, the South Iceland Seismic (transform) Zone and the Reykjanes peninsula oblique rift zone in southwest Iceland. The HTJ has the highest level of continuous seismic activity in Iceland (Einarsson, 1991) with 90000 events recorded between 1994 and 1999 (Sens-Schonfleder et al., 2003), and eleven probable $M>5$ events in the area between 1546 and 1998 (Clifton et al., 2002). Seismicity is restricted to depths of less than $7 \mathrm{~km}$ (Miller et al., 1998).

Several factors combine to make Thingvallavatn an ideal location to study tectonomagmatic interactions on timescales of thousands of years: 1) magmatic events from the Hengill volcano system are known to have interacted with the lake bed within the last two thousand years; 2) extensional faults and fissures run northeast from Hengill, are prominent on either side of the lake, and offset the lake bed; 3 ) the lake is predominately spring-fed and thus there is negligible detrital input except during volcanic eruptions; 4) interfingered diatomaceous sediment and volcanic ash layers record the history of fault movement within the lake; 5) the restricted sediment 
thickness (less than $25 \mathrm{~m}$ ) above a 9 ka lava allow the use of high frequency seismic reflection systems that give the best possible imaging of the entire stratigraphy above the lava.

Thingvallavatn was surveyed (Fig. 1) using a $100 \mathrm{kHz}$ sidescan sonar, a Chirp subbottom profiler ( $2-8 \mathrm{kHz}$ ) and GPS navigation. Both sidescan (150 line-km) and Chirp sub-bottom profiler data (200 line-km) were collected simultaneously with separate tow fish using a small research vessel, the Blaskel. The lake has a pronounced deep, west of Sandey (depth greater than 100 m, Fig. 1). Most of the lake has water depths of $40-80 \mathrm{~m}$, with prominent scarps representing the position of lava fronts and fault-related surfaces. Bull et al. (2003) discussed the large-scale tectono-magmatic interactions in northern Thingvallavatn, concluding that faulting and subsidence laterally ahead of diking associated with the emplacement of the Sandey scoria cone at 1.9 ka have been the dominant controls on the morphological evolution of the rift centered on Thingvallavatn. In this paper all scales of processes are reviewed for the entire lake, with a particular emphasis on constraining spatial and temporal changes in magmatic and tectonic behavior.

\section{GEOLOGICAL BACKGROUND}

Along the Western Rift Zone in southwestern Iceland magmatic activity is focused into several volcanic centers. Fissures and faults strike parallel to the rift zone and are concentrated close to the central volcanoes. The Hengill volcanic system lies just southwest of Thingvallavatn (Figs. 1,2) and comprises a central volcano and a fissure swarm. The Hengill fissure swarm extends northeastwards from Hengill, through Nesjavellir to Thingvellir, at an orientation of N27 - $29^{\circ} \mathrm{E}$ (Fig. 2). Faults and fissures have opened obliquely to the relative plate motion vector which is 19 $\mathrm{mm} \mathrm{yr}^{-1}$ in the direction $105^{\circ} \mathrm{E}$ (DeMets et al., 1994). The Hengill fissure swarm has formed a graben which contains Lake Thingvallavatn. The graben broadens to the northeast with increasing distance from Hengill.

The largest major faults controlling the last $9 \mathrm{kyr}$ of graben formation north of Thingvallavatn are the Almannagja fault system, forming the western margin, and the Hrafnagja fault system, controlling the eastern margin (Fig. 2). Gudmundsson (1987) reviewed these major faults in detail, and only the key points are repeated here. Almannagja is a $7.7 \mathrm{~km}$-long normal fault formed by the linkage of smaller segments. Towards the lake, the Almannagja fault changes into a set of en echelon fractures and the throw decreases. Almannagja has been recently active with Saemundsson (1992) estimating slip rates of $3 \mathrm{~mm} \mathrm{yr}^{-1}$ over the period $1971-1990$. The maximum total throw across this fault system is $40 \mathrm{~m}$. The Hrafnagja normal fault is $11 \mathrm{~km}$-long, with a throw of up to $14 \mathrm{~m}$ and comprises several open faults in an en echelon arrangement. Southwards, towards the lake, the fault dies out into a zone of parallel fractures, and net throw decreases (Gudmundsson, 1987; Saemundsson 1992).

South of Thingvallavatn, close to Hengill at Nesjavellir, the composite graben is asymmetric with strain concentrated to the northwest (Fig. 2). Saemundsson (1992) noted that much of this area was affected by extension 2 ka BP, perhaps immediately prior to the eruption of the Nesjahraun lava, as this lava covers many of the fault 
scarps. Saemundsson (1992) found also that faults around Hestvik (Fig. 1) showed indications of very recent activity.

Saemundsson (1992) summarised the products of volcanic eruption from the Hengill volcanic system: columnar-jointed sub-aerial lavas, pillow lavas and hyaloclastites. The loci of sub-glacial eruptions shifted periodically producing ridge systems such as Midfell (Fig. 2). Sub-aerial lava shields that formed during the 130 ka - 115 ka (Eemian) interglacial surround the southwest, east and far northeast of Thingvallavatn. Hyaloclastites and pillow lavas formed during the Weichselian glaciation (115 ka - $10 \mathrm{ka}$ ) both as sub-glacial ridges (Midfell) and supraglacial table mountains. Two major postglacial lava flows greatly affect the morphology and development of Thingvallavatn. The northern and eastern parts of the lake are floored by the Thingvallahraun lava flow which flowed from the northeast and has been dated as $9.14 \pm 0.26$ ka (Kjartansson, 1964). Elsewhere in the lake the Nesjahraun lava flow, which flowed from the flanks of Hengill at $1880 \pm 65{ }^{14} \mathrm{C}$ yrs BP (Saemundsson, 1992), forms acoustic basement.

The island of Sandey in the middle of the lake is a scoria cone formed at the same time as the eruption of the Nesjahraun lava at 1.9 ka (Saemundsson, 1992). Evidence supporting the temporal and magmatic linkage of the two events include: the stratigraphic position of the Sandey tephra in soils around Thingvallavatn; the alongstrike continuation of the Nesjahraun eruptive craters and the Sandey craters; and the presence of a submarine volcanic ridge linking Sandey with Hengill.

The lake is approximately $90 \%$ spring-fed (Adalsteinsson et al., 1992) and so there is very little surface inflow of sediments. Hence, sedimentation within the lake is dominantly from biogenic activity with minor wind-blown dust and volcanic particles. A $6 \mathrm{~m}$ piston core (Fig. 3) taken from Thingvallavatn in a water depth of 56 $\mathrm{m}$, recovered diatomaceous mud interdigitated with at least 36 tephra layers. One of these tephra layers has been identified as originating from Katla volcano (event K-E) at a depth of $5.2 \mathrm{~m}$ within the core (Geirsdottir et al., 1994; Hardardottir, 1999). Katla $\mathrm{K}-\mathrm{E}$ is typically $2-5 \mathrm{~cm}$ in thickness and has been dated at $2850 \pm 10{ }^{14} \mathrm{C}$ yrs BP (calibrated ages 2893-2903 cal BP, 2923-2941 cal BP, 2945-2966 cal BPRobertsdottir, 1992). This age control allows post-Katla K-E estimates of sedimentation rate of $1.76-1.79 \mathrm{~mm} \mathrm{yr}^{-1}$ at the core site. The presence of coarse distributed black tephra grains within the core between 3 - 3.5 m mark the Sandey eruptive event at $1.9 \mathrm{ka}$. The effect of the Sandey eruption is observed in the sediment above (to $140 \mathrm{~cm}$ ) which is massive and dense and has much lower total carbon percentage than sediment above and below. This sediment may represent debris flow deposits initiated by destabilisation of the sediment package following the Sandey eruption and/or the flow of the Nesjahraun lava into the lake.

For comparison, over the last $1.1 \mathrm{ka} \mathrm{BP}$, sedimentation rates of $0.4-2.4 \mathrm{~mm} \mathrm{yr}^{-1}$ were inferred from eight short (maximum length $0.8 \mathrm{~m}$ ) gravity cores (Haflidason et al., 1992), with the higher rates systematically occurring in deeper water. Fine parallel diatomite laminations between the tephra layers within the cores indicate weak to negligible bottom currents in deeper water (greater than $30 \mathrm{~m}$ ).

Figure 4 summarises the variation of sedimentation rate with water depth within the lake. Within water depths of less than $30 \mathrm{~m}$ there is negligible sedimentation 
throughout the lake, and this is interpreted as evidence for strong bottom currents driven by the dominant wind direction. Where sedimentation does occur in shallow water depths, it does so in small sediment drifts $5-8 \mathrm{~m}$ in thickness and up to $200 \mathrm{~m}$ in lateral extent. The data from Haflidason et al. (1992) indicate that the sedimentation rate for near-surface sediments increases with water depth from $1 \mathrm{~mm}$ $\mathrm{yr}^{-1}$ in $60 \mathrm{~m}$ of water to a maximum of $2.5 \mathrm{~mm} \mathrm{yr}^{-1}$ in $80 \mathrm{~m}$ of water.

\section{METHODS}

Data were acquired at a survey speed of 4 knots through the water, corresponding to $\sim 2-6$ knots over the ground. The Chirp data produced a single-fold seismic section with a shot interval of $0.5-1.0 \mathrm{~m}$. Chirp data in shallow water depths $(<60 \mathrm{~m})$ were collected in both uncorrelated and real-time correlated formats, while in deeper water depths only real-time correlated data were recorded. For more information on Chirp sub-bottom profilers see Bull et al. (1998). The record length was $133 \mathrm{~ms}$ and the sample interval was $40 \mu$ s. Navigation was by GPS with an uncertainty in position of $\pm 4 \mathrm{~m}$.

Enhanced resolution and signal-to-noise ratio over the real-time correlation was achieved by processing the uncorrelated Chirp data. This processing involved correlation with the Chirp source wavelet, signature deconvolution using the Klauder wavelet (the auto-correlation of the source wavelet), conversion to instantaneous amplitude, and application of a gain proportional to time. The correlated data were processed following the scheme developed by Quinn et al. (1998). This involved an Ormsby bandpass filter with corner frequencies of $0,30,2000$ and $2500 \mathrm{~Hz}$, resampling to $200 \mu \mathrm{s}$, Wiener-Levinson frequency-distance (F-X) deconvolution, and dynamic signal/noise filtering. The latter two processes selectively remove signals which are incoherent over a defined horizontal window length; windows of 10 and 20 traces, respectively, were used.

Data were migrated using a Kirchhoff diffraction stack approach (Schneider, 1978) with a limited aperture to account for the directionality of the Chirp source and receiver, which results in rather limited diffraction hyperbolae. Ideally the migration would also account for the variable shot spacing and the aperture would vary with water depth. For efficient processing of the large dataset, the mean shot spacing was calculated for each profile and a constant value used for each profile; this is a good approximation since speed over the ground varied little within individual profiles. In addition an approximately constant migration aperture of $20 \mathrm{~m}$ was used for the whole survey, by calculating the number of traces corresponding to $20 \mathrm{~m}$ from the mean shot spacing for each profile. For display, a tau-p domain coherency filter was applied which enhanced reflections with a dip of up to $0.1 \mathrm{~ms} /$ trace $\left(\sim 5-10^{\circ}\right.$ for typical trace spacings during the survey) over seven traces, and finally a nine-trace mix to further enhance coherent sub-horizontal reflectors and suppress migration artefacts.

The $100 \mathrm{kHz}$ sidescan data were collected with a line spacing and swath width of $800 \mathrm{~m}$ which resulted in $>90 \%$ coverage of the lakebed. The data were processed to give a $1.5 \mathrm{~m}$ per pixel resolution, mosaicked, and then overlaid upon a Landsat satellite image (Fig.2). 


\section{SIDESCAN SONAR INTERPRETATION}

Within the Landsat image (Fig. 2) the N27 - $29^{\circ} \mathrm{E}$ faults and fractures are principally imaged south and west of the lake. The bright even gray tone in the SW corner is the Nesjahraun lava which was erupted from a fissure on the flanks of Hengill, synchronously with the eruption of the Sandey scoria cone (Saemundsson, 1992). East of the lake, two hyaloclastite ridges (Arnarfell and Midfell) are imaged. The Sandey scoria cone is imaged within the centre of the lake.

The most prominent feature within the sidescan mosaic (Figs. 2a, 5) is the highly backscattering (white) flow front of the Thingvallahraun lava, which flowed from Eldborgir, northeast of the lake (Saemundsson, 1992; Sinton and Gronvold, 2001). The flow front has a typical scarp height at the lakebed of 30-45 m (Fig. 1), and is oriented east-west just north of Sandey, from where it can be traced towards the south, presumably continuing under Sandey following a fault-bounded submarine ridge to Nesjaey before anastomosing eastwards, surfacing at the eastern shore close to Midfell. The positive relief of Midfell onshore acted to deflect lava into the lake, and controlled the position of the lava front in the southern part of the lake. The eastwest orientation of this front west of Sandey indicates that the rift had little topographic relief there at the time of emplacement of the lava. Furthermore, the presence of the lava flow further south in the eastern lake suggests that the deepest part of the lake was further east at 9 ka than at present.

High backscatter within the sidescan data (Figs. 2a, 5) indicates that the Nesjahraun lava extends $2.5 \mathrm{~km}$ into the lake and abuts against the Thingvallahraun lava front. No flow front can be detected for the Nesjahraun lava, indicating a different mode of emplacement. As noted by Thors (1992), and supported by sub-bottom profiles discussed later, the Nesjahraun lava was emplaced rapidly as a slide.

Normal faults striking N27.6 $6^{\circ} \pm 4.3^{\circ} \mathrm{E}$ crop out on the lakebed, and are well imaged in the sidescan sonar data and the Chirp sub-bottom profiler data. Figure 2b illustrates the position of the faults deduced from both datasets, with the relative displacement on a fault indicated by the width of the fault in map view. Steep slopes in the deeper basin west of Sandey made discrimination of individual faults difficult. Faults are clearest in the lake bed north of Sandey, where the sedimentary history can be used to elucidate fault behavior.

An even gray tone on the sidescan mosaic indicates areas where there is a continuous sedimentary cover. The stipple texture is where the Thingvallahraun or Nesjahraun lavas outcrop with pockets of sediment infilling depressed areas. Bare lavas are imaged around the entire northern boundaries of the lake due to the lack of sedimentation in shallow water as discussed above.

\section{SEDIMENTARY AND STRATIGRAPHIC FRAMEWORK}

A Chirp sub-bottom profile through the $6 \mathrm{~m}$ core site (Fig. 6) has a seismic stratigraphy comprising a near-surface doublet followed by a strong reflector that can be followed throughout most of the lake. Imaging of deeper stratigraphy at the core site was prevented by the presence of gas which attenuates seismic wave propagation. 
In general gas was much more prevalent in the southern parts of the lake compared to the north, perhaps reflecting a greater thickness of sediments to generate the gas.

The variation in acoustic impedance down the $6 \mathrm{~m}$ core was determined from seismic velocity and density measurements. The impedance series was differentiated, convolved with the Chirp source signal and processed in the same way as the Chirp profiles (Quinn et al., 1998). This approach led to a synthetic seismogram dominated by the lakebed reflections. Compression of the core top occurred during coring, and to simulate this the impedance contrast at the lakebed was replaced with a linear gradient over a $20 \mathrm{~cm}$ interval, which resulted in a closer fit to the observed data. The synthetic seismogram produced (Fig. 3) suggests that acoustic impedance changes at the depth of the K-E event should give rise to a characteristic strong reflector that is observed in the Chirp records. This reflector (representing an age of c. $2.9 \mathrm{ka}$ ) and acoustic basement within the northern part of the lake (representing the 9.1 ka lava), provide constraints on the stratigraphic record of the lake floor (Table 1).

\begin{tabular}{|l|c|l|}
\hline Horizon & Age & Description \\
\hline Orange & $1.5 \pm 0.2 \mathrm{ka}$ & Lower of characteristic doublet, sub-parallels lake bed \\
\hline Purple & $\begin{array}{c}2.93 \pm 0.04 \\
\mathrm{ka}\end{array}$ & Strong reflector associated with tephra K-E \\
\hline Brown & $5.5 \pm 1.0 \mathrm{ka}$ & Overlies acoustically transparent zone \\
\hline Yellow & $9.1 \pm 0.3 \mathrm{ka}$ & Acoustic basement - Thingvallahraun lava \\
\hline
\end{tabular}

Table 1. Horizons interpreted within the Chirp sub-bottom profiles in Thingvallavatn. Orange and brown reflector ages were estimated on the basis of recent sedimentation rates and interpolation between the known ages of the purple and yellow reflectors.

Within the northern part of the lake, four prominent horizons were identified within the Chirp profiler records as shown in Table 1. South of Sandey the near-surface "Orange" reflector could usually be identified, and the "Purple" reflector could be patchily identified in the eastern part of the lake (Fig. 6). Throughout much of the southern part of the lake the presence of gas degrades the Chirp sub-bottom profiler data, limiting penetration. In addition irregular basement topography in the southwestern part of the lake makes correlation of sedimentary reflectors difficult.

Tephra deposits associated with the formation of the Sandey cone prevent imaging of older stratigraphy within the central part of the lake (Fig. 7). Sediment thickness ranges from 0 to $20 \mathrm{~m}$ above the Thingvallahraun lava, is generally c. $3-5 \mathrm{~m}$ within the central and southwestern part of the lake above hyaloclastite basement, but is interpreted to be greater than $25 \mathrm{~m}$ within the southeastern part of the lake because volcanic basement is not imaged by the Chirp profiler records. In shallow water depths in the western part of the lake, small sediment drifts formed by strong bottom currents are present, typically in the footwall of the fault closest to the western shore of the lake. 


\section{DEFORMATION RECORDED BY THE LAKE STRATIGRAPHY}

\section{Soft-sediment deformation associated with the Nesjahraun lava emplacement}

Within the southern part of the lake, east of the Nesjahraun lava and south of the Thingvallahraun lava front (Fig. 8), there is an area of pronounced near-surface softsediment deformation that is imaged in the Chirp profiles (Fig. 9). The diatomaceous sediments are complexly folded and faulted with typical fold wavelengths of 30 $100 \mathrm{~m}$, and amplitudes of up to $5 \mathrm{~m}$. The style of deformation is completely different to the basement fault controlled style seen elsewhere in the lake. In some parts of the soft-sediment deformation, the sediment appears to lose most of its internal structure.

In many places the deeper stratigraphy (e.g. the purple horizon in Fig. 9) appears less deformed than the overlying sediments. This is one of the major evidences that lead us to suggest that the impact of the Nesjahraun lava on the lakebed as the lava progressed into the lake caused liquefaction and folding of the near-surface $(<12 \mathrm{~m})$ soft sediments. We speculate that the deeper sediments were sufficiently consolidated that they were not disturbed by the impact. Overlying the deformed sequence, sedimentation during the last c. $1.5 \mathrm{kyr}$ has passively blanketed the area, and it is thus possible to constrain the timing of the soft-sediment deformation as being between 2.9 and $1.5 \mathrm{ka}$, consistent with the $1.9 \mathrm{ka}$ age of the Nesjahraun lava. The massive and dense unit above the Sandey event in the 6-m-long sediment core may represent debris flow deposits triggered by the emplacement of the Nesjahraun lava.

The juxtaposition of the soft-sediment deformation around the front of the Nesjahraun lava (Fig. 8) suggests that the physical impact of the lava on the lake sediments was a major factor in producing the folding observed. Factors controlling the spatial distribution of soft-sediment deformation include the dominant flow direction of the Nesjahraun lava as it entered the lake, and the presence of the Thingvallahraun lava front scarp acting as a rigid buttress, with deformation concentrated to the south of it. The range of soft-sediment deformational structures seen in Thingvallavatn suggests that the intensity of the deformation can change sharply over length scales of less than a km.

\section{Deformation of basement and sedimentary cover}

Whole-section extensional faulting is concentrated within the western part of Thingvallavatn (Fig. 2), with the southeastern part of the lake only affected by nearsurface soft-sediment deformation. The extensional faulting forms two composite narrow grabens in the southwestern part of the lake, but these merge close to Sandey and form a single broad graben north of Sandey (Fig. 2). The clearest faulting relationships are revealed by offsets in the 9.1 ka lava flow and subsequent sedimentation north of Sandey. The 1.9 ka Nesjahraun lava is offset by faulting in places (Fig. 2), and as noted onshore, the Nesjahraun undoubtedly covers older faults.

Strain estimates, calculated by summing vertical displacement values across all faults, were completed for the part of the lake north of Sandey (Fig. 10). Analysis in the southwest part of the lake is hampered by difficulties in discriminating fault- 
generated from volcanic relief, particularly where a volcanic ridge links Hengill with the islands of Nesjaey and Sandey.

The depth in two-way time (milliseconds) to the 9.1 ka lava is shown contoured in Figure 10, together with the major faults within the lake, and the most relevant faults and fissures onshore. The data show major easterly dipping faults at the western margin of the lake basin (F1 - 4 in Fig. 10) and a segmented eastern margin fault (F10a, b) which dips westwards. There is a major change in structural style across the line X-Y (Fig. 10) where fault F3 bifurcates, forming F1, fault F10 is offset into two separate segments F10a and F10b, and there is a change in the general dip of acoustic basement from gently dipping to the east (in the north, Figs. 11 and 12) to dipping to the west (in the south, Fig. 13). The major rift-bounding fault, F3, displaces the Thingvallavatn lava by up to $55 \mathrm{~m}$ in the region south of the line X-Y. This displacement is greater than the maximum displacement of these lavas observed subaerially along Almannagja. The displacement on F3 decreases sharply north of the line X-Y to $20-25 \mathrm{~m}$. Overall there is sharp depression of the rift floor by $25-30 \mathrm{~m}$ south of where the change in planform of faulting occurs. Fault segments F10a and F10b represent the major eastern rift-bounding fault and have maximum displacements of $45 \mathrm{~m}$ and $40 \mathrm{~m}$ respectively.

Changes in the structural style are illustrated with four representative Chirp profiles (Figs. 11 - 14). In the northernmost profile (Fig. 11), thin deposits of biogenic sediments can be seen infilling the lava surface with the thickest deposits towards the east. The northern tip of fault F3 is marked by a fold. Whereas top basement tilts west on most rotated fault blocks, the regional-scale lava surface dips towards the east with an average dip of $0.1-0.2^{\circ}$.

Moving south (Fig. 12), the relief on the western part of the graben is split between two faults (F1 and F3), whereas a single fault (F10b) marks the eastern boundary of the graben. The stratigraphy at the centre of the graben is marked by rotation of sedimentary reflectors within fault blocks, and changes in the thickness of intervals between blocks. Within a particular fault block, reflectors change from subhorizontal close to the lakebed to become progressively more rotated with depth, showing more deformation of the older sediments. There are also significant variations in the thickness of the interval just above basement - abrupt thinning/thickening suggesting that the faults were formed soon after emplacement of the Thingvallahraun lava and influenced the pattern of sedimentation. Folding and fissuring of the tip zone of fault F4 is evident.

South of the line X-Y, the Chirp profile (Fig. 13) has far greater relief than the profiles shown further north. On this profile, the lava surface on the rift floor dips 1$2^{\circ}$ towards the west, and the graben is asymmetric with far more displacement on the western faults than on the eastern faults. The thickest accumulation of sediment occurs mid-way between F3 and F10, but notably away from the deepest water depths. This observation is at variance with the evidence from gravity cores for increasing present-day sedimentation with increasing water depth as discussed earlier. From these observations we infer that fault F3 has moved recently and that there has been little time for sediment to accumulate. Bull et al. (2003) determined that the relatively thin sediment thickness in the hanging wall of fault F3 would have accumulated since 1.5-2.0 ka. 
Bull et al. (2003) interpreted the tectonic history of the northern part of Thingvallavatn in detail, using the sedimentary history to elucidate how faulting has evolved, and only the main points are discussed here. These authors made three key interpretations. Firstly, the major western bounding fault, F3, moved at 1.5 - 2 ka, facilitating rapid subsidence of $25-30 \mathrm{~m}$. Second, they demonstrated a systematic movement of the locus of sedimentation westwards towards F3 from 6 ka to $1.5 \mathrm{ka}$. Finally, the planform of faulting changes dramatically across line X-Y, and it is south of this line that fault F3 accumulated displacement rapidly between $1.5-2 \mathrm{ka}$. These authors argued that the observed rift geometry north of Sandey was similar to the predictions of numerical models of dike intrusion at depth. It was argued that the sudden large displacement accumulation on fault F3 could have occurred at the same time as the emplacement of the Nesjahraun lava and the formation of the Sandey scoria cone. These observations could be explained by the propagation of one or more dikes at depth between the Hengill volcanic system and Sandey at 1.9 ka, with deformation north of Sandey being consistent with models of deformation above an inflating propagating dike (Rubin, 1992). Three-dimensional elastic isotropic models would suggest that a series of dikes of total width $25 \mathrm{~m}$ would be required to produce the observed subsidence.

South of Sandey (Fig. 14), two narrow rift zones can be identified, separated by a volcanic ridge which links Hengill with the islands of Nesjaey and Sandey (Fig. 2). The width of the two rifts together is approximately the same as that of the single rift north of Sandey (compare with Fig. 13). Discrimination of volcanic relief from tectonically generated relief is difficult for the irregular volcanic ridge. Faults were identified on the basis of continuity along-strike identified from sidescan sonar images, rather than single scarps on a sub-bottom profile. The Thingvallahraun lava front is crossed in several places in Figure 14 (for position of the profile in relation to sidescan sonar data see Fig. 5) and a thicker sedimentary sequence is imaged on the southeastern end of the profile.

\section{STRUCTURAL ANALYSIS}

\section{Fault Displacement Scaling}

Faults displacing the 9 ka lava and overlying sediments are particularly well imaged north of Sandey, and Chirp profiles with a line spacing of $400 \mathrm{~m}$ were collected in this area. This dataset allowed the analysis of 35 faults ranging in length from $800 \mathrm{~m}$ to $3.5 \mathrm{~km}$. There were many small faults imaged on single profiles, but these are not considered further. In addition the length of faults will be underestimated due to spatial sampling restrictions.

Within the lake the maximum displacement on a single fault is $55 \mathrm{~m}$, with vertical displacements as small as $30 \mathrm{~cm}$ measurable in the Chirp data. While fault-related relief is routinely visible at the lakebed, determination of fault dip is made difficult by the presence of talus. Fault-generated scarps on the lake bed have dips ranging 
from $10^{\circ}$ to $70^{\circ}$ with a mean dip of $29^{\circ}$, whereas sub-vertical faults and fractures are reported onshore.

Fault populations from similar tectonic settings and offsetting materials with the same physical properties are predicted to exhibit similar displacement-length ratios (Cowie and Scholz, 1992). Within Thingvallavatn, for faults whose length was well constrained, the mean displacement-length ratio is 0.01 . This value for displacementlength ratio is consistent with values for normal fault systems on the Mid-Atlantic Ridge (a mean value of 0.016; Bohnenstiehl and Kleinrock, 2000), but greater than those reported on the East Pacific Rise (a mean value of 0.004; Cowie et al., 1994). However the observation that lava covers existing topography and faults raises some issues with displacement-length ratios both for the Thingvallavatn data and for data from mid-ocean ridges. Does the displacement-length ratio simply reflect the time span since the last volcanic eruption? Perhaps the smaller faults have displacementlength ratios which simply represent disruption of the top lava carapace and differ from those of the larger faults. Our dataset contains too few faults with wellconstrained fault lengths to be able to resolve such issues.

\section{Neotectonic Displacement Rates}

Throughout the northern part of the lake, the Thingvallahraun lava could be identified as acoustic basement and the vertical displacement since 9 ka could hence be determined from the offset of this reflector. The total vertical displacement for all faults (summing both west-dipping and east-dipping faults) within the northern part of the lake was summed and projected along a line $\mathrm{N} 27^{\circ} \mathrm{E}$ (Fig. 10). The maximum total vertical displacement is $130 \mathrm{~m}$ just north of Sandey, although displacement may continue to increase to the south, where seismic imaging is poor due to the steepness of the topography and the presence of the scoria cone.

Within the extreme north part of the lake there are no resolvable faults within either the sidescan or profiler records. However, immediately to the north, onshore displacement is concentrated to the west on the Almannagja fault, and to the east on the Hrafnagja fault (Fig. 1). Tryggvason (1974) found that the total vertical displacement across the rift zone since $9 \mathrm{kyr}$ was $110-130 \mathrm{~m}$. It is interesting to note that this displacement is close to the maximum vertical displacement observed within the lake. We suggest that the Almannagja and Hrafnagja faults, which parallel the northern sides of the lake, compensate for the reduction in displacement within the northernmost lake so that the net displacement along the rift remains constant. This hypothesis is supported by the observations of Gudmundsson (1987) on the onshore fault systems, where he noted a decrease in displacement towards the lake (on the Almannagja and Hrafnagja as discussed earlier). Some of the apparent decrease in displacement observed within the lake could be due to under-sampling of faults within the northernmost lake due to lack of sediment cover, but as the basement has subdued relief in that area (Fig. 10), we believe that any underestimation of displacement will be small.

The thickness of the 9 ka lava is not known onshore, but analysis of the lava flow front geometry in the lake indicates that this lava is thicker than $45 \mathrm{~m}$ in places. If the 
reasonable assumption is made that the 9 ka lava infilled and covered all the existing topography, then the subsidence and extension rate across the graben can be calculated for a range of normal fault dips. For the observed $110-130 \mathrm{~m}$ of total vertical displacement both onshore and offshore (Fig. 10), this equates to a subsidence rate of $6-7 \mathrm{~mm} \mathrm{yr}^{-1}$. This is somewhat greater than the modern observations of Tryggvason reported by Saemundsson (1992) estimating $1 \mathrm{~mm} \mathrm{yr}^{-1}$ subsidence of the graben floor over a period of 23 years from 1967 to 1990. The discrepancy most likely originates from the episodic nature of the deformation on individual faults or fault groups (e.g. the Almannagja has been estimated to have moved at $3 \mathrm{~mm} \mathrm{yr}^{-1}$ for the period 1971-1990, Saemundsson, 1992), and comagmatic subsidence. If these observations are representative, only $1 / 7$ of deformation is steady and 6/7 of deformation occurs during short-lived tectonic and magmatic events.

Present-day deformation of the Hengill volcanic system was investigated by Feigl et al. (2000) using Interferograms over a four year (1993-1996) period. They found aseismic motion on a short segment of a normal fault in August 1995 with dip-slip movement of $8 \mathrm{~mm}$. The rest of the signal in the Interferograms was from secular uplift interpreted as increasing pressure caused by magma accumulation. An inflating volume source at $7 \mathrm{~km}$ depth in an elastic half-space best described the concentric deformation. Thus a contribution from episodic magma inflation could also explain the discrepancy between the subsidence observations. However caution is needed in comparing vertical motion observations on timescales of a few years with aggregate observations determined over thousands of years.

As noted previously it is not possible to constrain fault dip within the lake due to the widespread presence of talus. Grant and Kattenhorn (2004), on the basis of field observations and numerical modeling assuming elastic behavior, argue that the fault and fissures at the surface onshore are formed by the propagation upwards of normal fault with dips of $60-75^{\circ}$. This range of fault dips is consistent with the observations of Angelier et al. (1997) of normal fault dips, in a similar rift environment near Krafla, of $60-72^{\circ}$. Evidence for similar high-angle fault planes deeper in the crust in the western rift zone is shown by accurate hypocenter location of small magnitude earthquake activity using local earthquake tomography, with near-vertical clustering of hypocentres at depths of $4-6 \mathrm{~km}$ orientated along zones trending northeast (Figure 10 in Miller et al., 1998; Miller, 1996).

Given the range of vertical displacement observed, a range of fault dips of $60-75^{\circ}$ would suggest a total extension of $30-75 \mathrm{~m}$. If the assumption is made that the 9.1 ka lava infilled all of the pre-existing topography, then these values indicate an extension rate of $3.3-8.2 \mathrm{~mm} \mathrm{yr}^{-1}$. Geodetic estimates of extension across the Thingvellir rift of $3 \mathrm{~mm} \mathrm{yr}^{-1}$ (observations made between 1967 and 1979 and summarised by Tryggvason, 1982) and the most recent GPS geodetic data for the period 1992-1995 (Alex et al., 1999) are broadly consistent with the extension estimate derived using an average fault dip of $75^{\circ}$. However, these extension rate estimates are much smaller than the NUVEL-1A value for the total plate boundary extension rate of $19 \mathrm{~mm} \mathrm{yr}^{-1}$ (DeMets et al., 1994). If we assume that the entire North America - Europe plate motion was taken up purely by tectonic extension across the Thingvellir rift, we can work out the effective fault dip implied by the $110-130 \mathrm{~m}$ of vertical displacement over the last $9 \mathrm{kyr}$. As the NUVEL-1A NAM-EUR plate 
motion predicts $170 \mathrm{~m}$ of extension during this period, the faults would need to have dips of $33-37^{\circ}$. Based on a variety of evidence, including the results of local earthquake hypocentre location, such low dips are unlikely, so a significant proportion of the plate motion must be taken up by deformation outside the rift (e.g. on the East Rift Zone of Iceland or the South Iceland Seismic Zone) or our estimate of extension since $9 \mathrm{ka}$ underestimates the long-term extension rate due to incomplete sampling of the episodic magmatic component. Using preferred estimates of fault dip $\left(60-75^{\circ}\right)$, Thingvellir accounts for some $17-43 \%$ of the plate motion. This percentage might be increased by up to $5 \%$ if the obliquity of the fault strike compared to the plate motion vector and block rotation by up to $2^{\circ}$ since 9 ka are accounted for.

\section{Monoclines and Fault Propagation}

As discussed above, Grant and Kattenhorn (2004) argue that, at Thingvellir, north of Thingvallavatn, narrow monoclinal folds were formed by the propagation to the surface of normal faults. These folds are subsequently breached by the upward propagating normal faults with the formation of vertical faults and open fissures above the upward propagating fault. Grant and Kattenhorn (2004) invoke a 50-150 m wide surface monocline on the hanging wall side of the Almannagja fissure to demonstrate convincingly their arguments, with the upper hinge line of the monocline being breached by en echelon fractures.

All the seismic data collected in the lake have been closely analysed for evidence of monoclines ahead of upward propagating faults. Where faults have large displacements there is no evidence for pre-cursory development of monoclines in the seismic reflection data. In particular there is no sign of curvature on the 9.1 ka lava surface adjacent to the fault surface; evidence suggests that the faults broke through the surface without previous folding. However, at the northern tips of major faults (F3 and F4, Fig. 11 and 12) there is good evidence of monocline development. At the northern tip of F3 (Fig. 11) a monocline with a width of c. $300 \mathrm{~m}$ and amplitude of $12 \mathrm{~m}$ is present. The subsequent breaching of a tip monocline is illustrated for F4 (Fig. 12) where several small fissures are present in the axis of the monocline. In addition, there is evidence for monocline formation in the early history of the smaller faults within the centre of the graben (see inset box to Fig 13 for an example).

A possible explanation for the apparent absence of monoclines associated with major faults in the lake is related to the blanketing of pre-existing topography and faulting by the 9.1 ka lava flow. Where strain was accommodated by displacement on the centre of major pre-existing faults, the fault propagated upwards and broke the 9.1 lava flow without the development of a monocline on the lava surface. However, where faults have propagated vertically and laterally, then a monocline develops at the fault tip. Subsequent faulting then breaches these monoclines. Monoclines may well be more widely present under the 9 ka lava, but their observation using the nearsurface geophysical techniques utilised here was not possible. The sparse observation of fault tip monoclines is consistent with a well-developed pre- 9 ka fault system under Thingvallavatn. 


\section{SUMMARY OF THE EVOLUTION OF LAKE THINGVALLAVATN}

In this paper, we have explored the detailed effects of tectonic and magmatic processes on the generation of the Thingvellir rift and Lake Thingvallavatn since the formation of the lake at the end of the last glaciation at c. $10 \mathrm{ka}$ BP. Our interpretation of the recent evolution of Lake Thingvallavatn is illustrated in Figure 15 which shows that the morphology of the northern part of the lake has changed significantly.

The Thingvallahraun lava erupted at $9.1 \mathrm{ka}$ and flowed into a broad depression. The lava filled in most of the pre-existing topography, buried fault traces and caused a reduction in the size of the lake. The only outlet for lake waters at the Sog (Fig. 1) was blocked at this time (Saemundsson, 1992), and the water deepened, partially submerging the newly erupted lava. On the southern lake shore, the lake flooded areas west of the Sog (Fig. 15), as indicated by the preservation of laminated diatomaceous sediment onshore. Over the next $4 \mathrm{kyr}$, incremental extension across the rift caused subsidence and accumulation of sediment, particularly within the central part of the rift, resulting in the topography shown at 5 ka in Figure 15a. At this time fault F10 and associated faults along-strike further south appear to have been most active, giving rise to an asymmetrical rift with the rift floor dipping to the east.

Extension and subsidence across the rift continued between $5 \mathrm{ka}$ and $1.9 \mathrm{ka}$ with a progressive westward migration of the locus of subsidence and sedimentation (Bull et al., 2003). At 1.9 ka the lake morphology was greatly altered by the Hengill-Sandey event. The event included the eruption of the Nesjahraun lava and deformation of soft sediments within the lake, formation of the Sandey scoria cone and associated thick tephra deposits, and faulting and subsidence within the northern part of the lake. Bull et al. (2003) argued that the faulting and subsidence in the northern lake occurred ahead of a propagating dike at depth that linked Hengill and Sandey. Figure 15b illustrates the lake at this time with the emplacement of the Nesjahraun lava, formation of Sandey, and the generation of major faults along the western margin of the northern lake (Faults F1 - F4). These faults changed the form of the rift floor north of Sandey from dipping to the east, to dipping to the west, with displacement particularly accumulating on F3 (X-X', Fig. 15b). At the tips of the faults F3 and F4 monoclines were developed (Y-Y', Fig. 15b).

Faults F1-F3 are along strike of the Almannagja fissure, and there may well be direct linkage between the onshore and offshore fissures. The observation of a monocline at Almannagja suggests that lateral fault propagation from major faults within the lake northwards may have occurred as recently as 1.9 ka, given that F3 moved at this time. The relationship between formation of the Almannagja monocline and the 1.9 ka Hengill-Sandey event is speculative, and it is not possible to constrain the rate of lateral fault propagation outside of the lake. While Bull et al. (2003) concluded that lengthening of faults must be less than $25 \mathrm{~mm} \mathrm{yr}^{-1}$, it is clear that further constraints on the rate of lateral fault propagation will require greater data density over fault tips within Thingvallavatn. 
From 1.9 ka to the present day (Fig. 15c), tectonically driven extension and subsidence has occurred with accumulation of sediment predominantly in the deepest parts of the lake. There is evidence that tip monoclines developed by 1.9 ka have been disrupted by later faulting (F3 in Y-Y', Fig. 15c).

While there have been studies of grabens formed above and laterally ahead of propagating dikes on mid-ocean ridges (Chadwick and Embley, 1998) these studies have generally studied smaller magnitude dike events with dike widths of $1-3 \mathrm{~m}$. In this study it is argued that a series of dikes of $25 \mathrm{~m}$ total-thickness fed the Sandey eruption and caused faulting and subsidence laterally ahead of the propagating dike. This study has shown that movement on fault F3 caused the formation of an asymmetrical rift with the rift floor now dipping to the west. Profiles of grabens formed at the Cleft and Coaxial segments of the Juan de Fuca Ridge in response to diking (Chadwick and Embley, 1998) do sometimes show asymmetry, but the interaction with contemporaneous lava infilling the fault-derived topography, makes interpretation difficult. Curewitz and Karson (1998) argue that single diking events at slow-spreading ridges will only produce 'local' effects on ridge-axis morphology. Here we show that for large diking events the entire rift geometry can be changed both above and up to $3 \mathrm{~km}$ ahead of the propagating dike.

\section{CONCLUSIONS}

In this study the well-constrained lake stratigraphy, specifically the lava acoustic basement $(9.1 \pm 0.3 \mathrm{ka})$ and three younger horizons $(5.5 \pm 1.0 \mathrm{ka}, 2.93 \pm 0.04 \mathrm{ka}$ and $1.5 \pm 0.2 \mathrm{ka}$ ), enabled detailed study of the main tectonic and magmatic events that affected the development of Thingvallavatn. We show that a single diking event changed the large-scale morphology of the western rift zone. Furthermore:

1. A major Hengill volcanic event that controlled the development of the presentday lake morphology occurred at $1.9 \mathrm{ka}$, with the eruption of a scoria cone within the lake (Sandey). In this event, the Nesjahraun lava was erupted into the southern lake, the Sandey scoria cone was formed, and significant faulting and subsidence (up to 25 $\mathrm{m}$ ) occurred in the northern lake. The major diking at $1.9 \mathrm{ka}$ changed the large-scale morphology of the lake, and resulted in an asymmetric rift.

2. In the northern part of the lake, normal faults oriented at $\mathrm{N} 27.6 \pm 4.3^{\circ} \mathrm{E}$ form a broad $5 \mathrm{~km}$-wide graben, whereas two narrow grabens are present in the south close to Hengill. Analysis of fault displacement relief formed on a 9.1 ka lava flow (Thingvallahraun) both within the lake, and onshore north of the lake, reveals that the total vertical displacement is spatially constant at $110-130 \mathrm{~m}$ along a line-projected parallel to the mean fault-strike. Using preferred estimates of fault dip (60-75'), Thingvellir accounts for some $17-43 \%$ of the total plate boundary extension 
(relative to NUVEL-1A). This analysis indicates that either deformation is accommodated elsewhere in Iceland (for example along the Eastern Rift Zone, and the South Iceland Seismic Zone) or that short-term measurements of extension across the area underestimate the long-term extension rate due to incomplete sampling of episodic magmatic events.

3. Within the southern part of the lake, prominent liquefaction phenomena are interpreted as associated with the emplacement of the Nesjahraun lava, with soft sediments being faulted and deformed into folds with wavelength $30-100 \mathrm{~m}$, and amplitude of up to $5 \mathrm{~m}$.

4. Fault propagation monoclines are imaged close to fault tips in north Thingvallavatn. Their apparent absence towards the centre of faults is due to the covering of the existing fault fabric and associated monoclines by a thin lava carapace at $9.1 \mathrm{ka}$. With subsequent deformation, faults propagated upwards without folding the overlying lava surface at the centre of the larger faults. This observation, together with little evidence for lateral propagation of faults over the last $9 \mathrm{kyr}$, is consistent with a well-developed pre-9.1 ka fault system.

\section{ACKNOWLEDGEMENTS}

This project was supported by the Royal Society of London and the equipment used was funded by the Natural Environment Research Council under research grant GR3/9533. Royal Society University Research Fellowships supported TAM and NCM. The $6 \mathrm{~m}$-long sediment core was originally acquired and analysed using funds from the Icelandic Research Council and National Science Foundation. We are grateful to Kjartan Thors and Angus Best for logistical support and expertise in Iceland, and Tim Le Bas for help with processing of the sidescan sonar data. The manuscript was improved by careful reviews from Cindy Ebinger and Simon Kattenhorn.

\section{REFERENCES CITED}

Adalsteinsson, P.M., Jonasson, P.M., and Rist, S., 1992, Physical characteristics of Thingvallavatn: Oikos, v. 64, p. 121-135

Angelier, J., Bergerat, F., Dauteuil, O., Villemin, T., 1997, Effective tension-shear relationships in extensional fissure swarms, axial rift zone of northeastern Iceland: Journal of Structural Geology, v. 19, p. 673-685.

Alex, N., Einarsson P., Heinert, M., Niemeyer, W., Ritter, B., Sigmundsson, F., Willgalis, S., 1999, GPS-Messkampagne 1995 zur Bestimmung von Deformationen der Erdkruste in Sudwestisland: Zeitschrift fur Vermessungswesen., v. 124, p. 347-361.

Bohnenstiehl, D.R., and Kleinrock, M.C., 2000, Evidence for spreading-rate dependence in the displacement-length ratios of abyssal hill faults at mid-ocean ridges: Geology, v. 28, p. 395-398.

Brandsdottir, B., and Einarsson, P., 1979, Seismic activity associated with the September 1977 deflation of Krafla volcano in north-eastern Iceland: Journal of Volcanological and Geothermal Research, v. 6, p. 197-212. 
Bull, J.M., Quinn, R., and Dix, J.K., 1998, Reflection coefficient calculation from marine high-resolution seismic reflection (Chirp) data: Marine Geophysical Researches, v. 20, p. 1-11.

Bull, J.M., Minshull, T.A., Mitchell, N.C., Thors, K., Dix, J.K., and Best, A.I., 2003, Fault and magmatic interaction within Iceland's western rift over the last 9 kyr: Geophysical Journal International, v. 154, p. F1-F8.

Cervelli, P., Segall, P., Amelung, F., Garbeil, H., Meertens, C., Owen, S., Miklius, A., and Lisowski, M., 2002, The September 12, 1999 Upper East Rift Zone dike intrusion at Kilauea Volcano, Hawaii: Journal of Geophysical Research, v. 106, DOI 10.1029/2001JB000602.

Chadwick, W.W., and Embley, R.W., 1998, Graben formation associated with recent dike intrusions and volcanic eruptions on the mid-ocean ridge: Journal of Geophysical Research, v. 103, p. 9807-9825.

Clifton, A.E., Sigmundsson, F., Feigl, K.L., Gudmundsson, G., and Arnadottir, T., 2002, Surface effects of faulting and deformation resulting from magma accumulation at the Hengill triple junction, SW Iceland, Journal of Volcanological and Geothermal Research: v. 115, p. 233-255.

Cowie, P.A., and Scholz, C.H., 1992, Physical explanation for displacement-length relationship for faults using a post-yield fracture mechanics model: Journal of Structural Geology, v. 14, p. 1133-1148.

Cowie, P.A., Malinverno, A., Ryan, W.B.F., and Edwards, M.H., 1994, Quantitative fault studies on the East Pacific Rise: A comparison of sonar imaging techniques: Journal of Geophysical Research, v. 99, p. 15205-15218.

Curewitz, D., and Karson, J.A., 1998, Geological consequences of dike intrusion at Mid-Ocean Ridge spreading centers, in: Faulting and Magmatism at Mid-Ocean Ridges, Geophysical Monograph, American Geophysical Union, v. 106, p. 117-135.

DeMets, C., Gordon, R.G., Argus, D.F., and Stein, S., 1994, Effect of recent revisions to the geomagnetic reversal time scale on estimates of current plate motions: Geophysical Research Letters, v. 21, p. 425-478.

Einarsson, P., 1991, Earthquakes and present-day tectonism in Iceland: Tectonophysics, v. 189, p. 261-279.

Feigl, K.L., Gasperi, F., Sigmundsson, F., and Rigo, A., 2000, Crustal deformation near Hengill volcano, Iceland 1993-1998: Coupling between magmatic activity and faulting inferred from elastic modeling of satellite radar interforograms: Journal of Geophysical Research, v. 105, p. 25655-25670.

Geirsdottir, A., Hallsdottir, M., Larsen, G., Hardardottir, J., Norddahl, H., Eiriksson, J., Thors, K. and Helgadottir, G., 1994, Setmyndum i sunnlenskum stoduvotnum. In: Geoscience Society of Iceland. Spring Meeting. Conference Proceedings, Reykjavik, The Geoscience Society of Iceland, p.7.

Grant, J.V., and Kattenhorn, S.A., 2004, Evolution of vertical faults at an extensional plate boundary, southwest Iceland: Journal of Structural Geology, v. 26, p. 537-557. 
Gudmundsson, A., 1987, Tectonics of the Thingvellir fissure swarm, SW Iceland: Journal of Structural Geology, v. 9, p. 61-69.

Haflidason, H., Larsen, G., Olafsson, G., 1992, The recent sedimentation history of Thingvallavatn, Iceland: Oikos, v. 64, p. 8095.

Hardardottir, J., 1999, Late Weichselian and Holocene environmental history of south and west Iceland as interpreted from studies of lake and terrestrial sediments [Ph. D. Thesis]: Boulder, University of Colorado, 332p.

Kjartansson, G., 1964, The retreat of the last glacial ice sheet and some volcanoes in the Kjolur area: Natturufraedingurinn, v. 34, p. $101-113$.

Miller, A.D., 1996. Seismic structure and earthquake focal mechanisms of the Hengill Volcanic Complex, S. W. Iceland [Ph. D. Thesis]: University of Durham, 280p.

Miller, A.D., Julian, B.R., and Foulger, G.R., 1998. Three-dimensional seismic structure and moment tensors of non-doublecouple earthquakes at the Hengill-Grensdalur volcanic complex, Iceland: Geophysical Journal International, v. 133, p. 309325.

Pollard, D.D., Delaney, P.T., Duffield, W.A., Endo, E.T., and Okamura, A.T., 1983, Surface deformation in volcanic rift zones: Tectonophysics, v. 94, p. 541-584.

Quinn, R., Bull, J.M. and Dix, J.K., 1998, Optimal processing of marine high-resolution seismic reflection (Chirp) data: Marine Geophysical Researches, v. 20, p. 13-20.

Robertsdottir, B.G., 1992, Forsoguleg gjoskulog fra Kotlu, adur nefnd "Katla 5000”. Geological Society of Iceland - spring meeting, Abstracts, Reykjavik, p. 8-9.

Rubin, A.M., 1992, Dike-induced faulting and graben subsidence in volcanic rift zones: Journal of Geophysical Research, v. 97, p. 1839-1858.

Saemundsson, K., 1992, Geology of the Thingvallavatn area: Oikos, v. 64, p. 40-68.

Schneider, W.A., 1978, Integral formulation for migration in two and three dimensions: Geophysics, v. 51, p. 324-331.

Sens-Schonfelder, C., Korn, M., Stefansson, R., 2003, Patterns in the seismicity of the Hengill area in southwest Iceland: Geophysical Research Abstracts. v. 5, 01512.

Sinton, J.M., and Gronvold, K., 2001, Post-glacial eruptive history of the western volcanic zone, Iceland: Eos Transactions of the American Geophysical Union, v. 82, Abstract T42C-0951.

Taylor, S.K., Bull, J.M., Lamarche, G., and Barnes, P.M., 2004, Normal fault growth and linkage during the last 1.3 million years: an example from the Whakatane Graben, New Zealand: Journal of Geophysical Research, v. 109, B02408, doi:10.1029/2003JB002412. 
Tryggvason, E., 1974, Vertical crustal movement in Iceland, in (Eds) Kristjansson, L. Geodynamics of Iceland and the North Atlantic Area. Reidel, Dordrecht, p. 241-262.

Tryggvason, E., 1982, Recent ground deformation in continental and oceanic rift zones, in G. Palmason (eds), Continental and Oceanic Rifts. AGU Geodynamic Series, v. 8, p. 17-29.

Figure 1. Bathymetric map of Thingvallavatn with contours in meters. Positions of Chirp sub-bottom profiles are shown by the dotted lines. The white dot shows the position of a 6-m-long sediment core. $\mathrm{N}$ is the island of Nesjaey. Inset shows the position of the lake $(T)$ on plate boundary zone in Iceland. HTJ is Hengill Triple Junction; SISZ is South Iceland Seismic Zone; WRZ is Western Rift Zone; RR is Reykjanes Ridge. Stipple indicates volcanic zones, and the arrows describe the relative plate motion vector (DeMets et al., 1994).

Figure 2. (a). Sidescan mosaic of the lakebed plotted with positive polarity (high backscatter in white) within a Landsat image. Black areas denote sidescan data gaps. (b) Interpretation of the lakebed data. The positions of major normal faults identified from the Chirp profiler and sidescan sonar data are indicated by the elongate dark gray areas, with the tick marks indicating the down-thrown side. The large faults on the western side of the lake dip towards the east and those on the eastern side dip towards the west forming the graben. The width of the fault traces are proportional to the displacement at the lakebed determined from sidescan sonar and Chirp records. Dark shading around Sandey indicates approximate extent of the scoria cone. Light gray shading shows the extent of the 9.1 ka lava flow (Thingvallahraun). Intermediate shading in the southern part of the lake marks the 1.9 ka (Nesjahraun) lava. The Landsat data were used to map the Nesjahraun lava onshore. The ' $v$ ' notation shows areas of the lakebed where lavas are exposed as indicated by bright back-scatter on the sidescan data and rugged morphology in Chirp records. The dashed regions show parts of the lakebed which have continuous sediment cover. The positions of faults and fissures onshore were derived from Saemundsson (1992) and most can also be observed in the Landsat data. $\mathrm{N}$ denotes the island Nesjaey. The box shows the area of enlarged sidescan data shown in Figure 5.

Figure 3. Core TH94 interpretation, impedance and correlation with Chirp profiler data. The position of Core TH94 is shown in Figure 2. The left panel shows an interpretation of the core by Hardardottir (1999). The core contains fine-grained diatomaceous sediment interdigitated with numerous tephra layers. The position of the Sandey eruptive tephra was identified as shown, as is the position of tephra K-E. The right panel shows an acoustic impedance log constructed from density and velocity measurements made with a geophysical core logger. The central panel shows a comparison of the correlated (real) Chirp data (a stack of 10 adjacent traces acquired over the core site) and a synthetic constructed by convolving the impedance data with the Chirp source wavelet. See main text for a full description of the analysis. A strong reflective event associated with Katla K-E was interpreted across much of the lake.

Figure 4. Variation in sedimentation rate with water depth within Thingvallavatn. In deeper water, Haflidason et al. (1992) found a simple linearly increasing 
sedimentation rate with water depth. In shallow water $(<30 \mathrm{~m})$ around the lake margins there is uneven sediment deposition indicating strong current activity, whereas, in water depths greater than $60 \mathrm{~m}$, laminated diatomite sediments indicate low bottom current strength.

Figure 5. Enlargement of the sidescan mosaic of a lava front and normal faulting located by box in Figure 2. The prominent east-west trending anastomosing bright boundary is the front of the Thingvallahraun lava flow, which flowed from the northwest and has an average scarp height in this area of $20 \mathrm{~m}$. Letters $\mathrm{I}$, J, and $\mathrm{K}$ refer to parts of the Thingvallahraun lava front imaged on the Chirp profiler data in Figure 14. In the southwest corner of the image the younger Nesjahraun lava is imaged as the speckled texture representing little sediment cover. Even gray backscatter texture indicates areas with continuous sediment cover. In the northwest corner of the image, three NE-SW trending normal faults are imaged, all down-throwing to the northwest (see also Fig. 14). Normal faults imaged here are buried by the Nesjahraun lava, indicating there has not been significant motion on these faults since the emplacement of the lava at $1.9 \mathrm{ka}$. An interpretation of this image is shown in Figure $2 b$.

Figure 6. A Chirp profile through the position of the $6 \mathrm{~m}$ sediment core TH94-01. The strong reflective event towards the base of the core was correlated with Katla event K-E (see synthetic seismogram in Fig. 3), and is described elsewhere as the Purple reflector. The acoustic doublet, in this profile paralleling the lakebed, is another characteristic reflection event that was interpreted within the lake. The lower reflector of the doublet is termed the "Orange" reflector. Shallow gas can be seen preventing imaging of the "Purple" horizon at CDPs 4300-4450, and this shallow gas was irregularly present particularly in the southeast part of the lake. Vertical exaggeration is 1:10.

Figure 7. Chirp profile within the central lake run parallel to tectonic structure (see Fig. 1 for position). This profile runs from the volcanic ridge, which links Hengill to Nesjaey and Sandey, northwards to the east of Sandey into the well-sedimented northern part of the lake. The flank of the Sandey scoria cone is prominent within the centre of the profile. The Orange horizon (c. $1.5 \mathrm{ka}$ ) can be seen in the northern lake onlapping onto the scoria cone. The Thingvallahraun lava is not well imaged on this profile but underlies the northern $1 \mathrm{~km}$ of the profile at c. $82 \mathrm{~ms}$ TWT. Vertical exaggeration is $1: 50$.

Figure 8. Map showing distribution of deformed near-surface sediments (dashed lines) within the southern part of the lake which are interpreted as liquefied sediments. The positions of the Nesjahraun lava (dark gray shading) and Thingvallahraun lava (light gray shading) are also shown, together with the positions of Chirp profiles in Figure 6 and Figure 9.

Figure 9. Chirp profile showing a package of deformed sediments within the southern part of the lake. The deformed sediment package is $7-8 \mathrm{~m}$ thick and complexly folded and faulted. The near-surface sediments are undeformed and passively drape the deformed package. At depth the Purple 2.9 ka reflector is imaged and appears to be relatively undeformed. The deformed sediment package is related to the impact of 
the Nesjahraun lava on soft near-surface sediments at $1.9 \mathrm{ka}$. Vertical exaggeration is $1: 9$.

Figure 10. Analysis of vertical displacement on faults within the northern lake. (A) Contours show two-way time (milliseconds) to the $9.1 \mathrm{ka}$ Thingvallahraun lava surface which acts as acoustic basement together with the positions of major normal faults (solid gray). The width of the fault traces are proportional to the displacement at the lakebed determined from sidescan sonar and Chirp records. Positions of three Chirp sections shown in Figures 11 - 13 are shown. The diamond shapes ahead of faults F3 and F4 indicate the position of tip monoclines (see also Fig. 11). (B) Total vertical displacement on faults within the lake (solid line) and onshore (dotted line) projected onto line J-J'. This line has the same orientation $\left(\mathrm{N} 27^{\circ} \mathrm{E}\right)$ as the average trend of the fault system. The onshore fault displacement data are from Tryggvason (1974). Note that the onshore and offshore displacement profiles are kinematically coherent and result in a constant vertical displacement along the rift of 110-130 m.

Figure 11. Uninterpreted (A) and Interpreted (B) Chirp profile across the broad northern graben, north of Sandey (see Fig. 1 for location). The vertical exaggeration is $1: 25$. The 9.1 ka lava flow is indicated by the yellow horizon; faults are marked in red.

Figure 12. Uninterpreted (A) and Interpreted (B) Chirp profile across the broad northern graben, north of Sandey (see Fig. 1 for location). The vertical exaggeration is 1:25. The major western faults (F1 and F3) are marked, as is the major eastern boundary fault (F10b).

Figure 13. Uninterpreted (A) and interpreted (B) Chirp profile north of Sandey (see Fig. 1 for location). The vertical exaggeration is 1:18. Inset in $\mathrm{B}$ shows horizons described in Table 1. The 9.1 ka lava flow is indicated by the yellow horizon, whereas faults are marked in red.

Figure 14. Chirp profile south of Sandey (see Fig. 1 for location). The vertical exaggeration is 1:15. Note the two narrower rifts separated by a volcanic ridge south of Sandey in contrast to the single broad rift north of Sandey shown in Figure 13. The profile crosses the Thingvallahraun lava flow front in several locations; I, J, and $\mathrm{K}$ refer to features on the sidescan mosaic shown in Figure 5.

Figure 15. Interpreted evolution of the lake from 5 ka to present. Ornamentation and annotation as in Figure 2. In the maps, the dark dashed line shows where the position of the lake boundary differed from the present day (Saemundsson, 1992). In the crosssections, the $\mathrm{v}$ hatching is the top of the Thingvallahraun, while the layered hatching represents the infill of diatomaceous sediment. A - $\mathbf{5}$ ka. The map shows the lake 4 kyr after the emplacement of the Thingvallahraun lava flow. The cross-sections show that a modest graben existed with the major faults occurring in the eastern lake. B 1.9 ka. This map shows the lake soon after the Hengill-Sandey event at 1.9 ka when the Nesjahraun lava was emplaced, the Sandey scoria cone was formed, and major subsidence occurred in the northern part of the lake. The major western boundary faults formed at this time (cross-section X-X) and the lakebed subsided c. 25 m. Note 
that the thickest sediment is now away from the deepest water depth. The tip of fault F3 is associated with a fault-tip fold on the more northerly section Y-Y'. C - Present Day. Sedimentation has continued covering the lakebed morphology that was formed at $1.9 \mathrm{ka}$. 


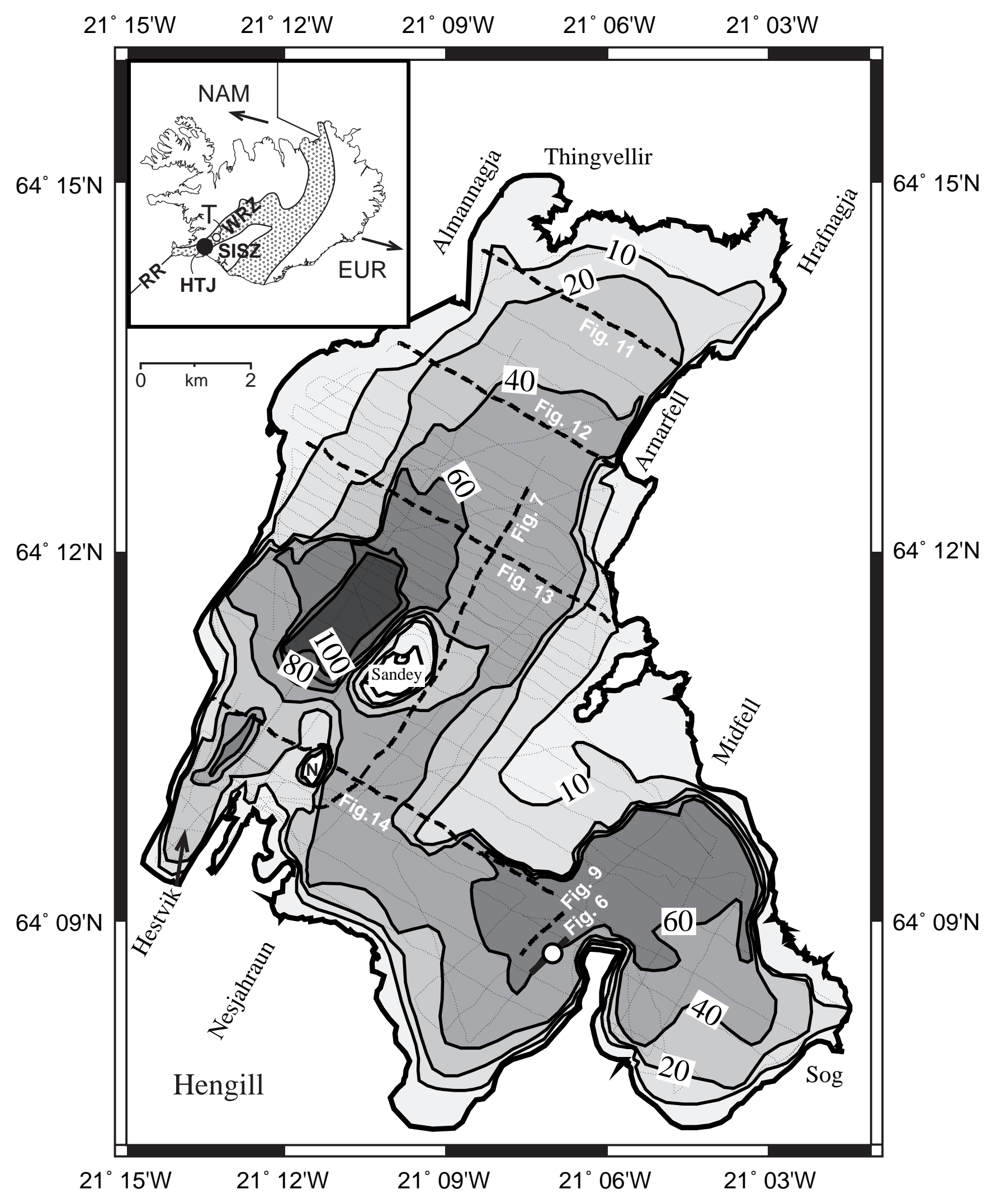

Figure 1 

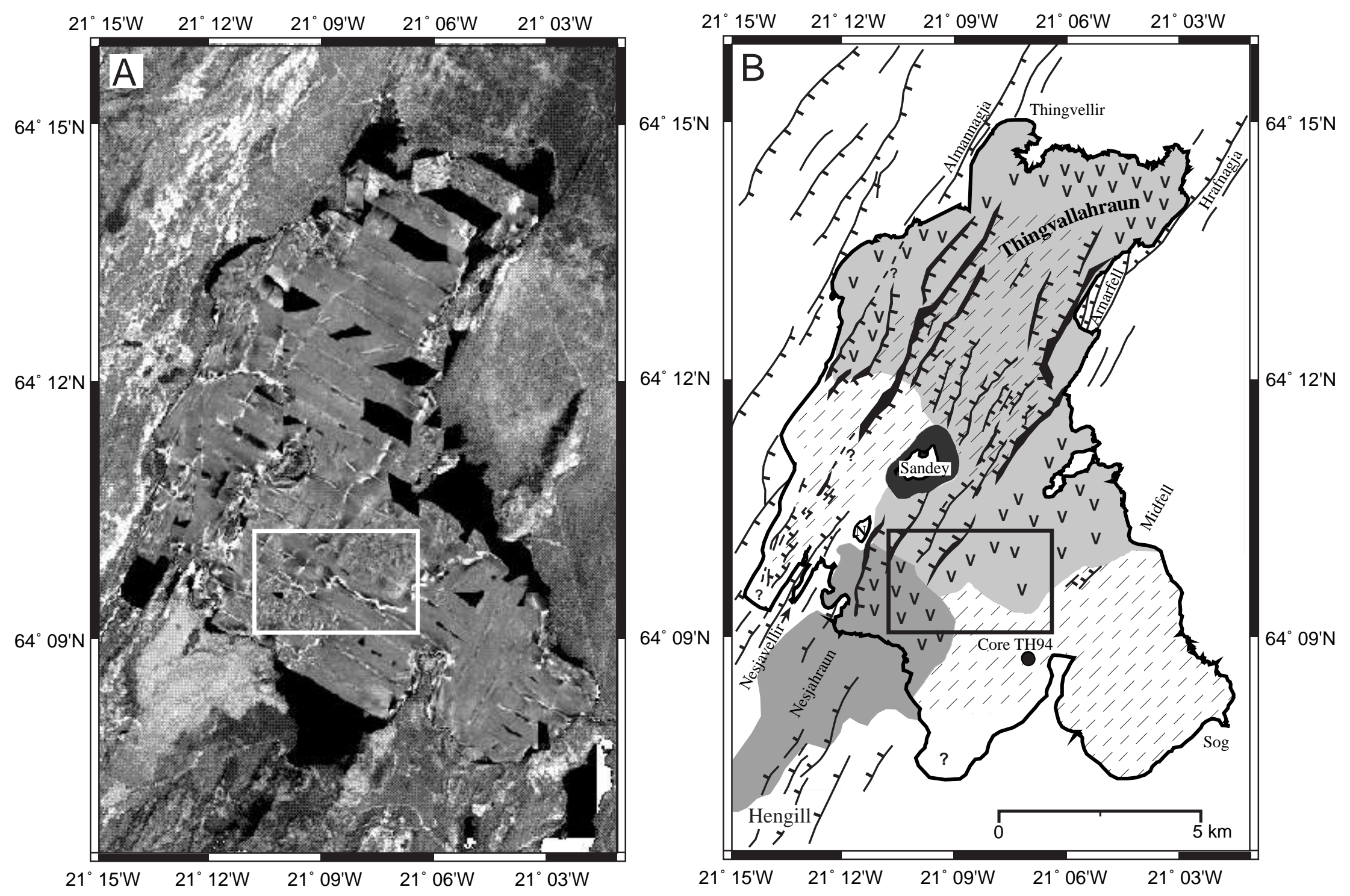

Figure 2 


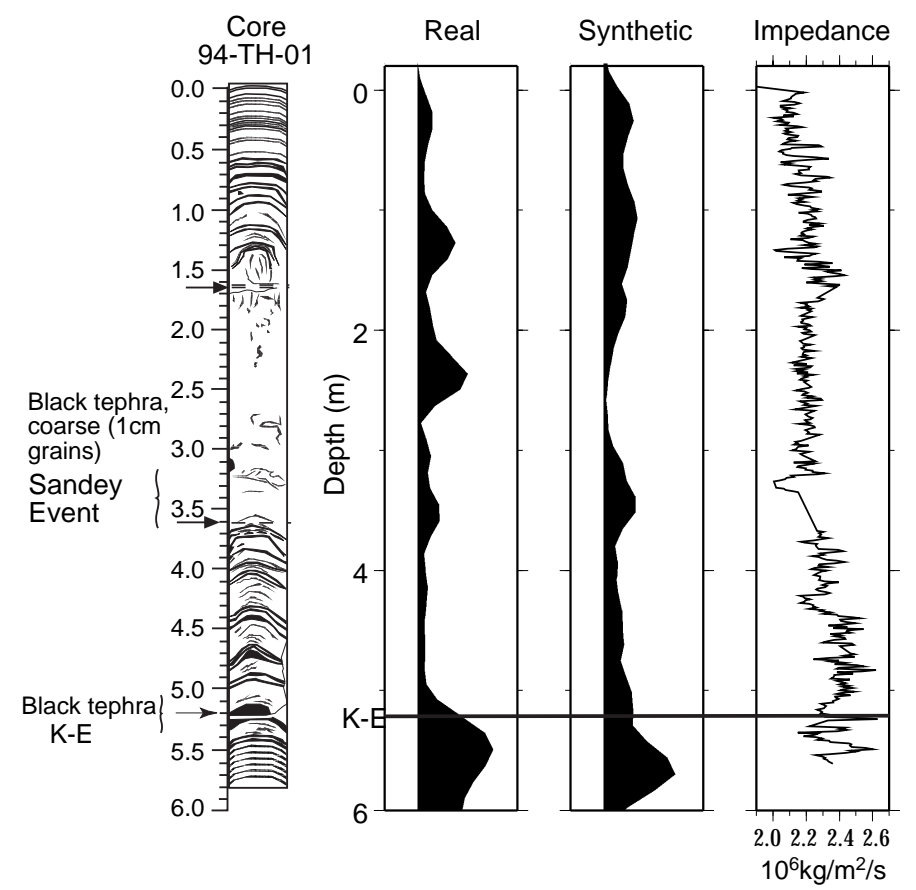

Figure 3 


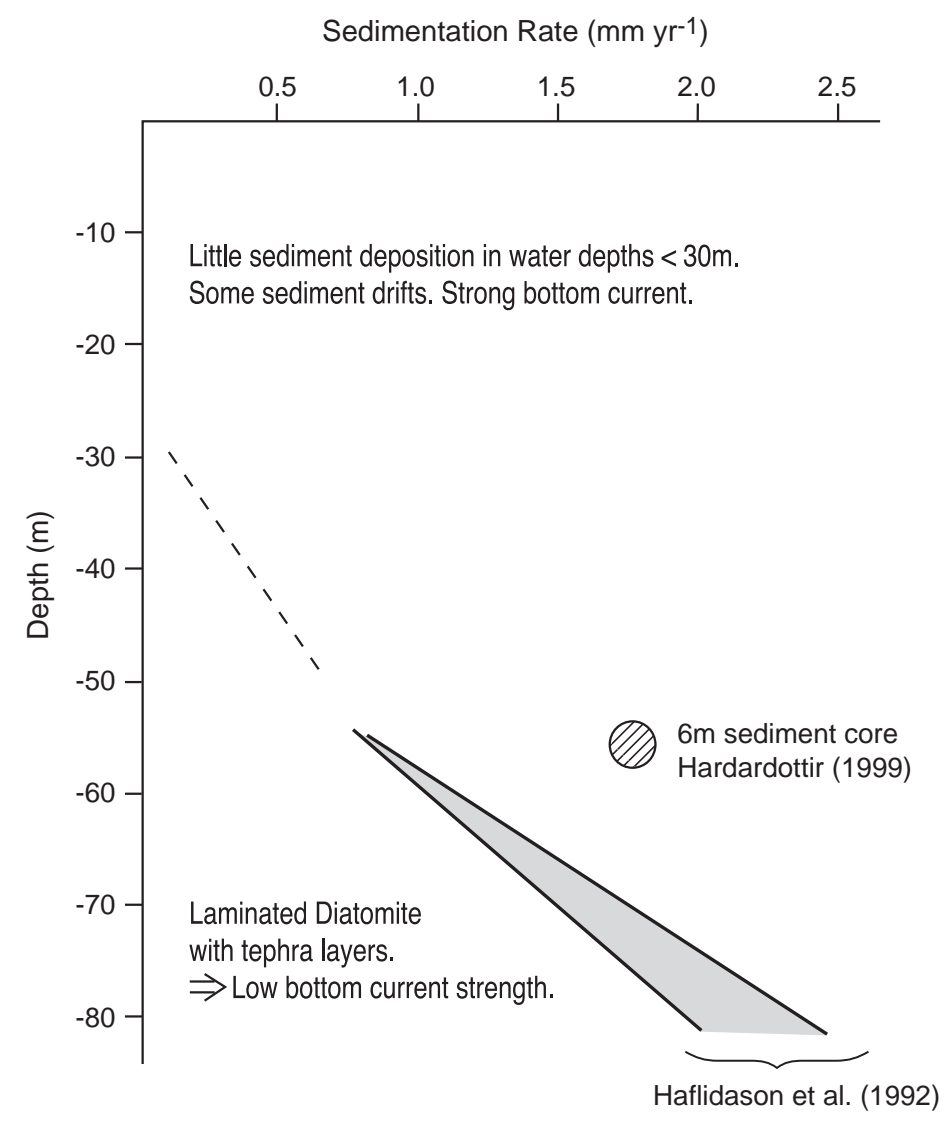

Figure 4. 
Figure 5.

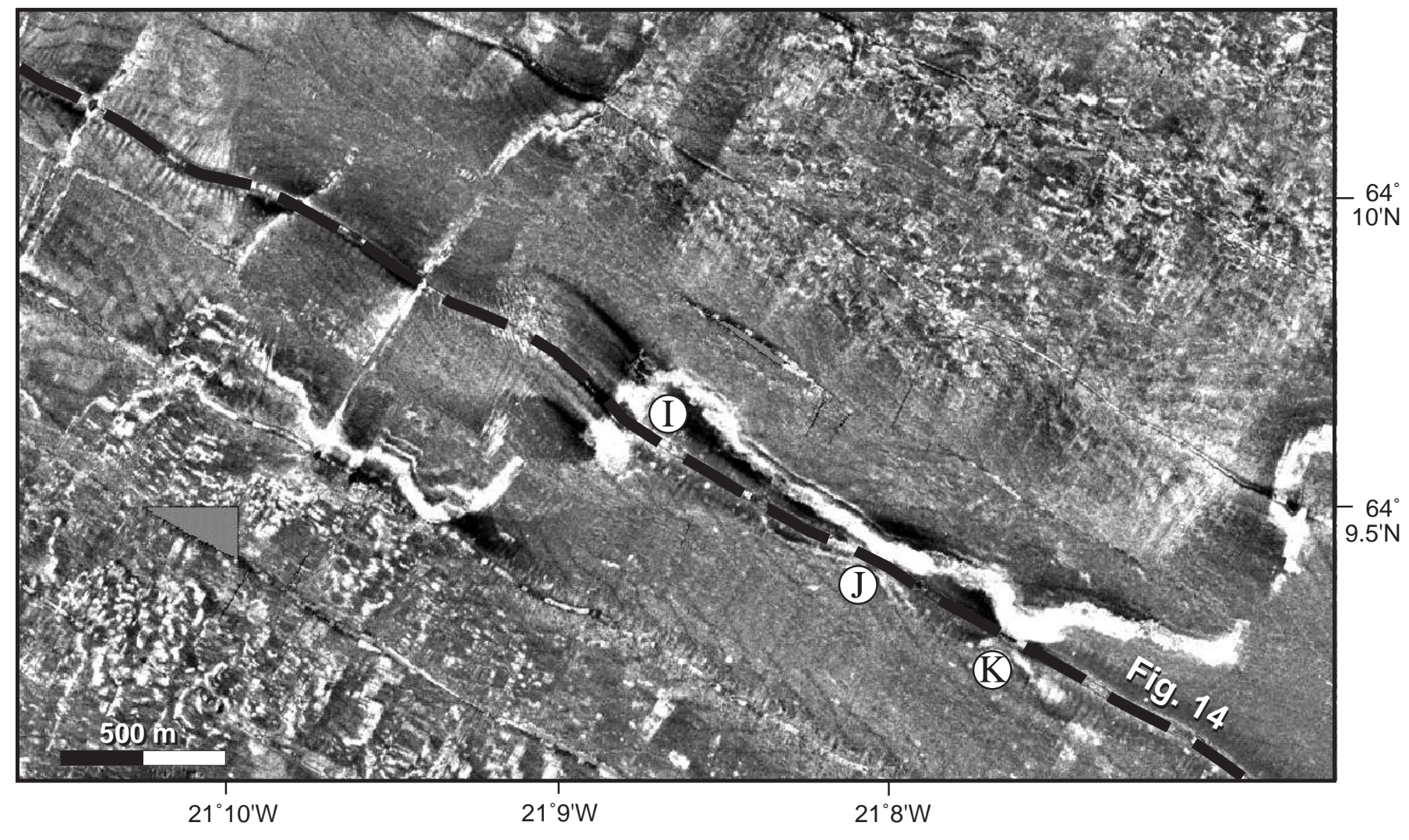




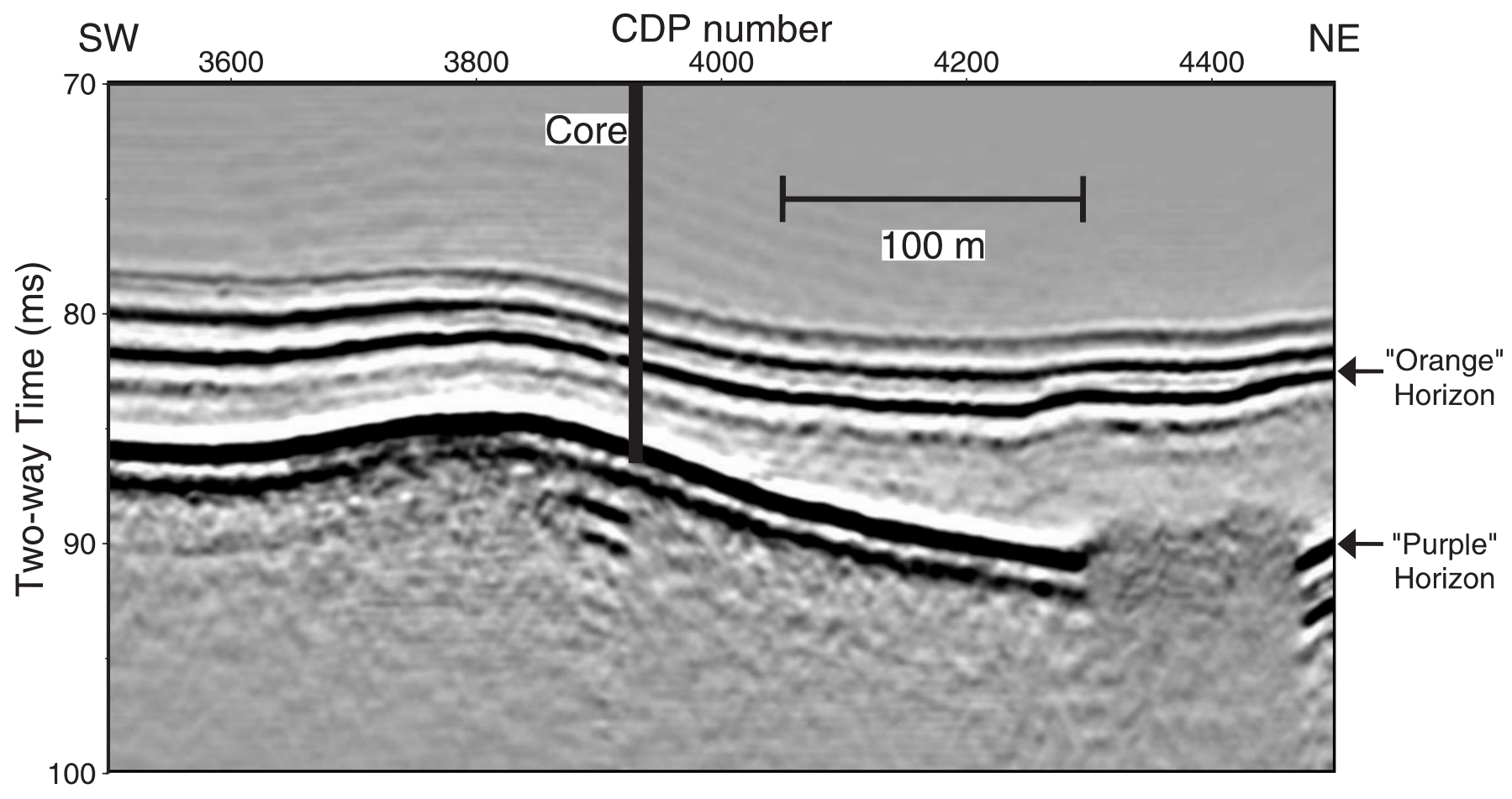

Figure 6 
Figure 7.

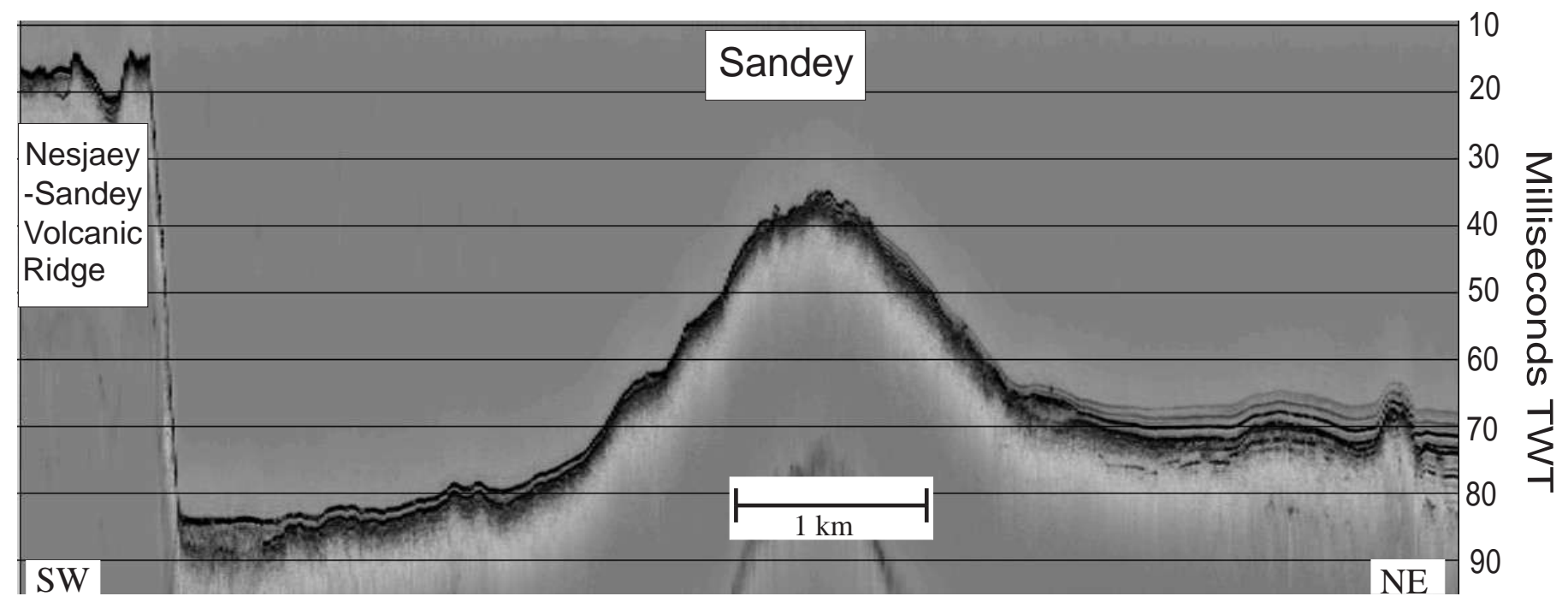


Figure 8.

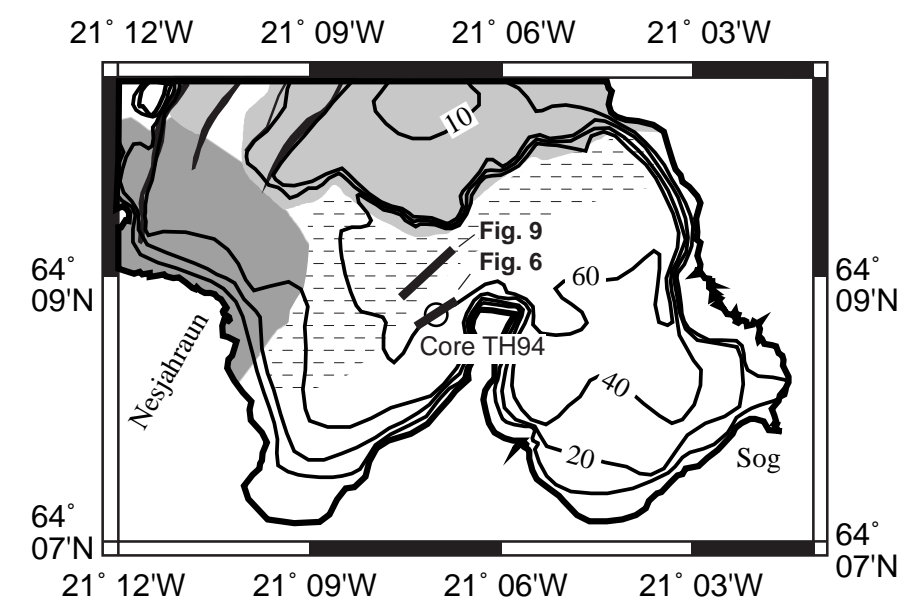




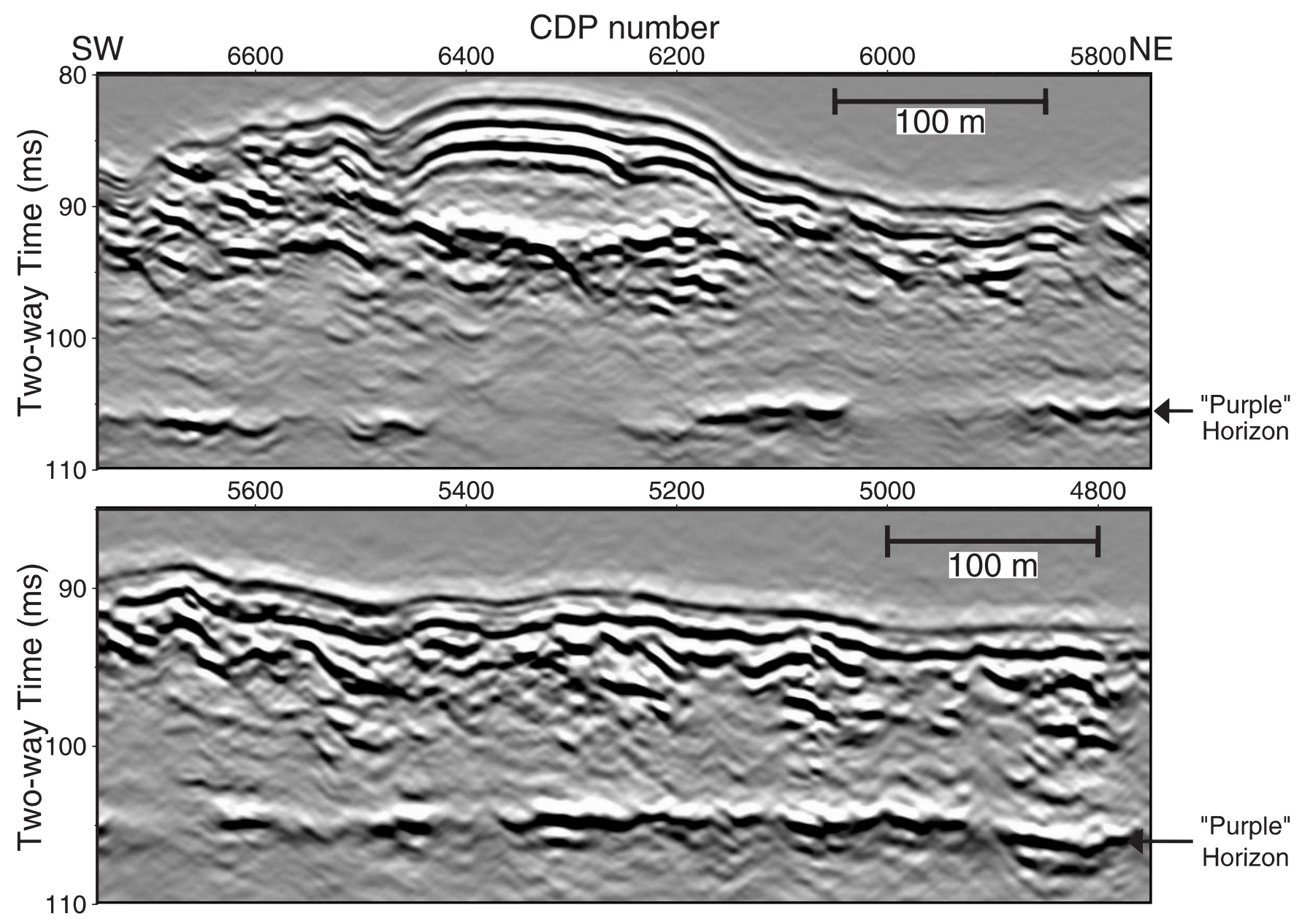

Figure 9. 

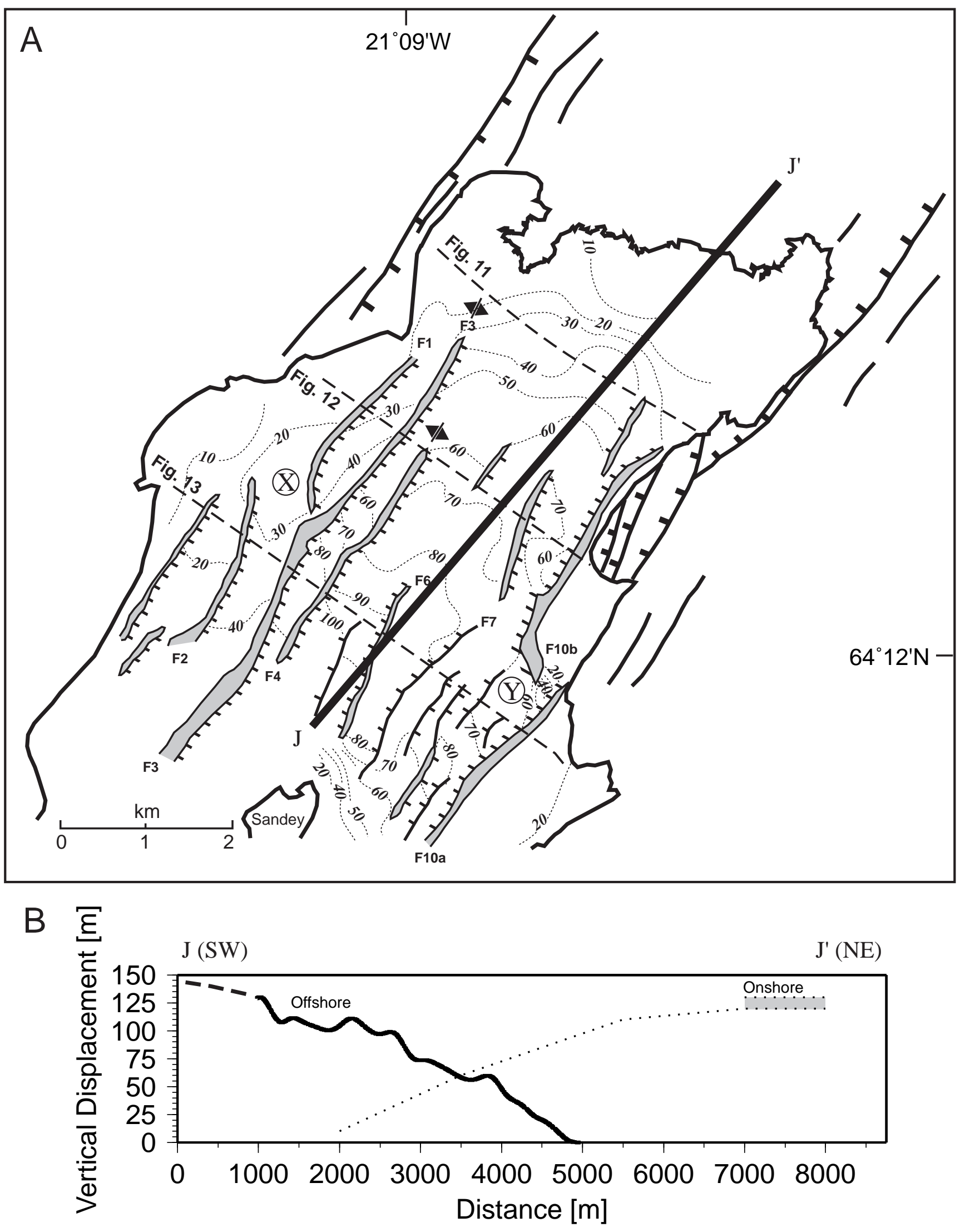

Figure 10. 


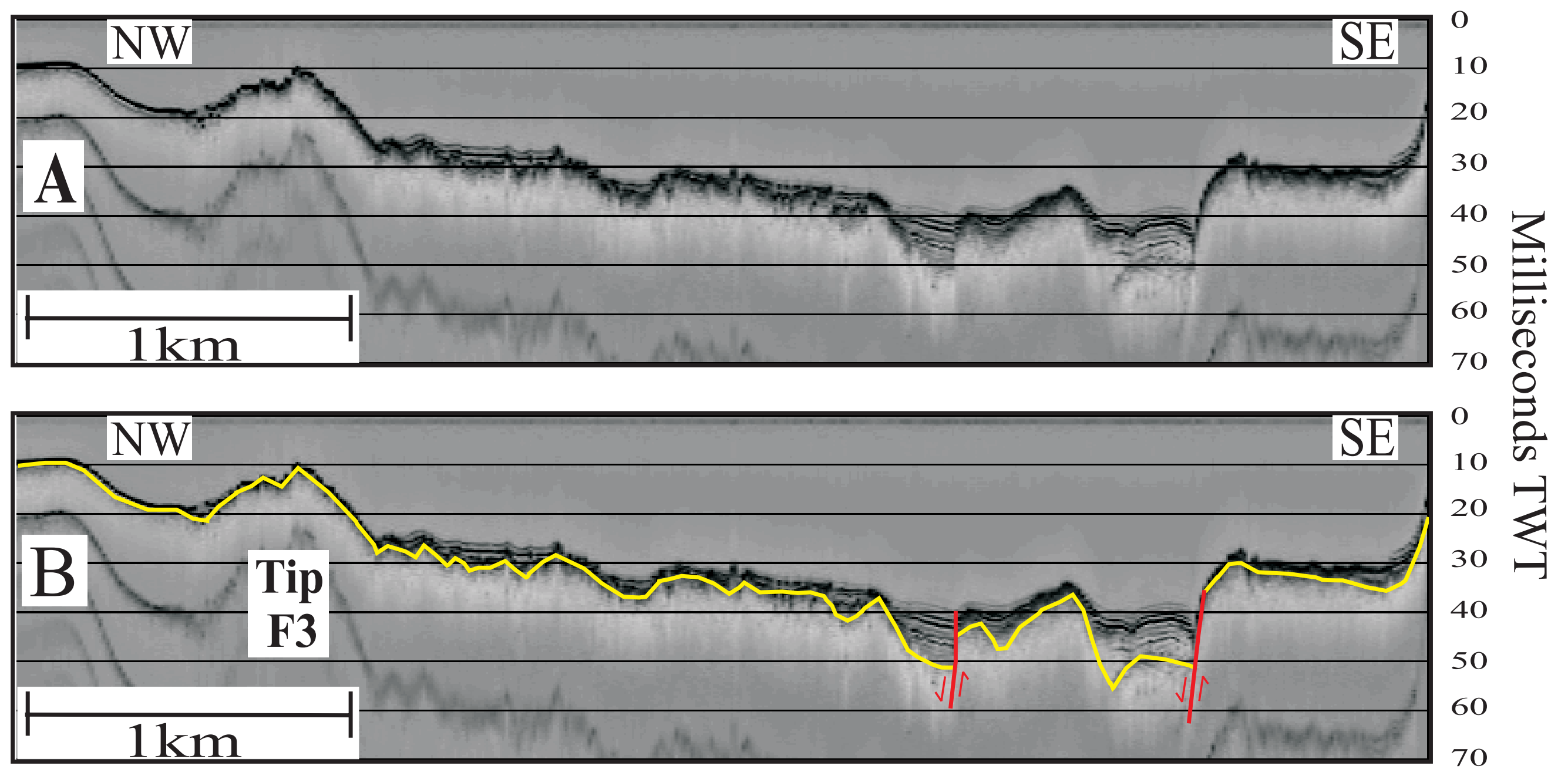

Figure 11. 

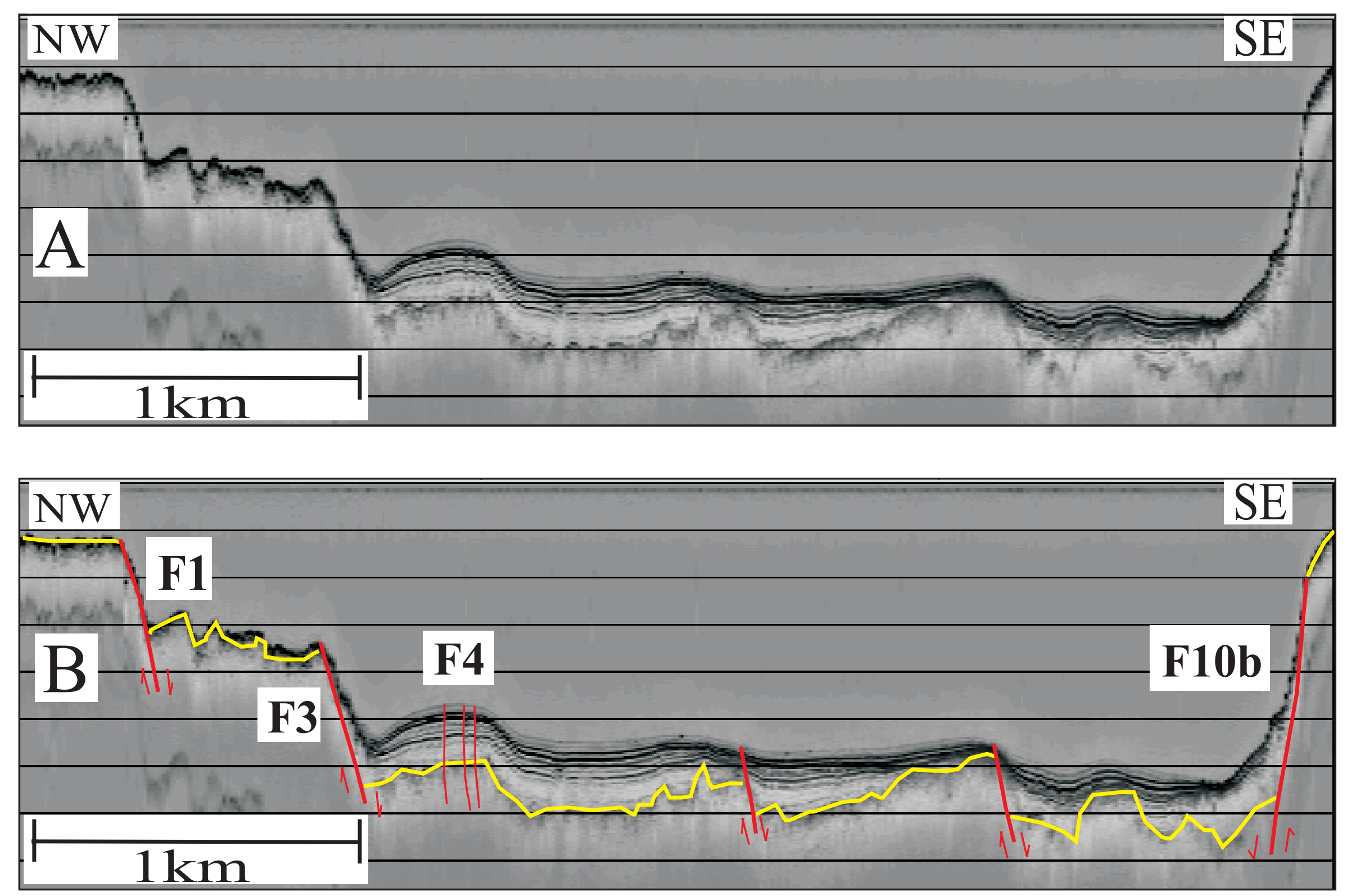

Figure 12. 

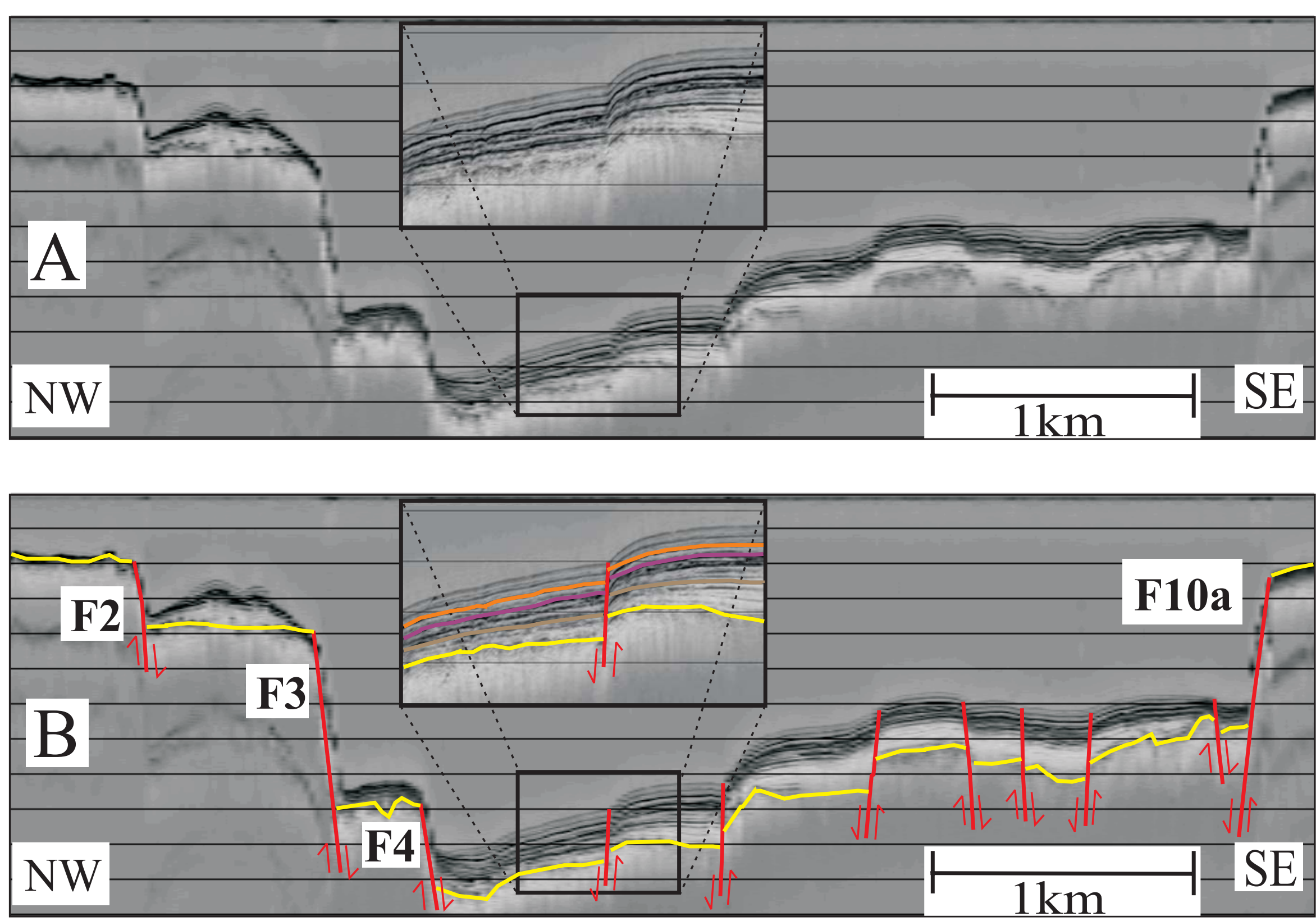

Figure 13. 


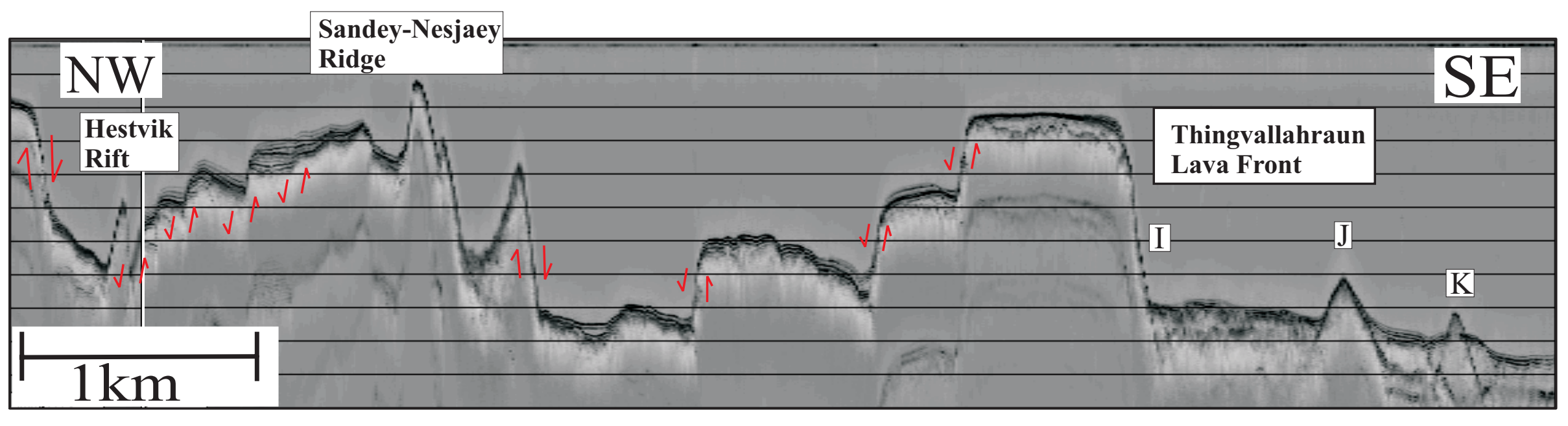

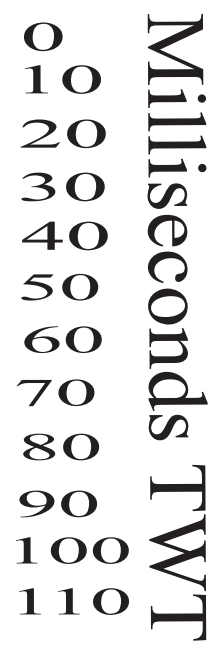

Figure 14. 


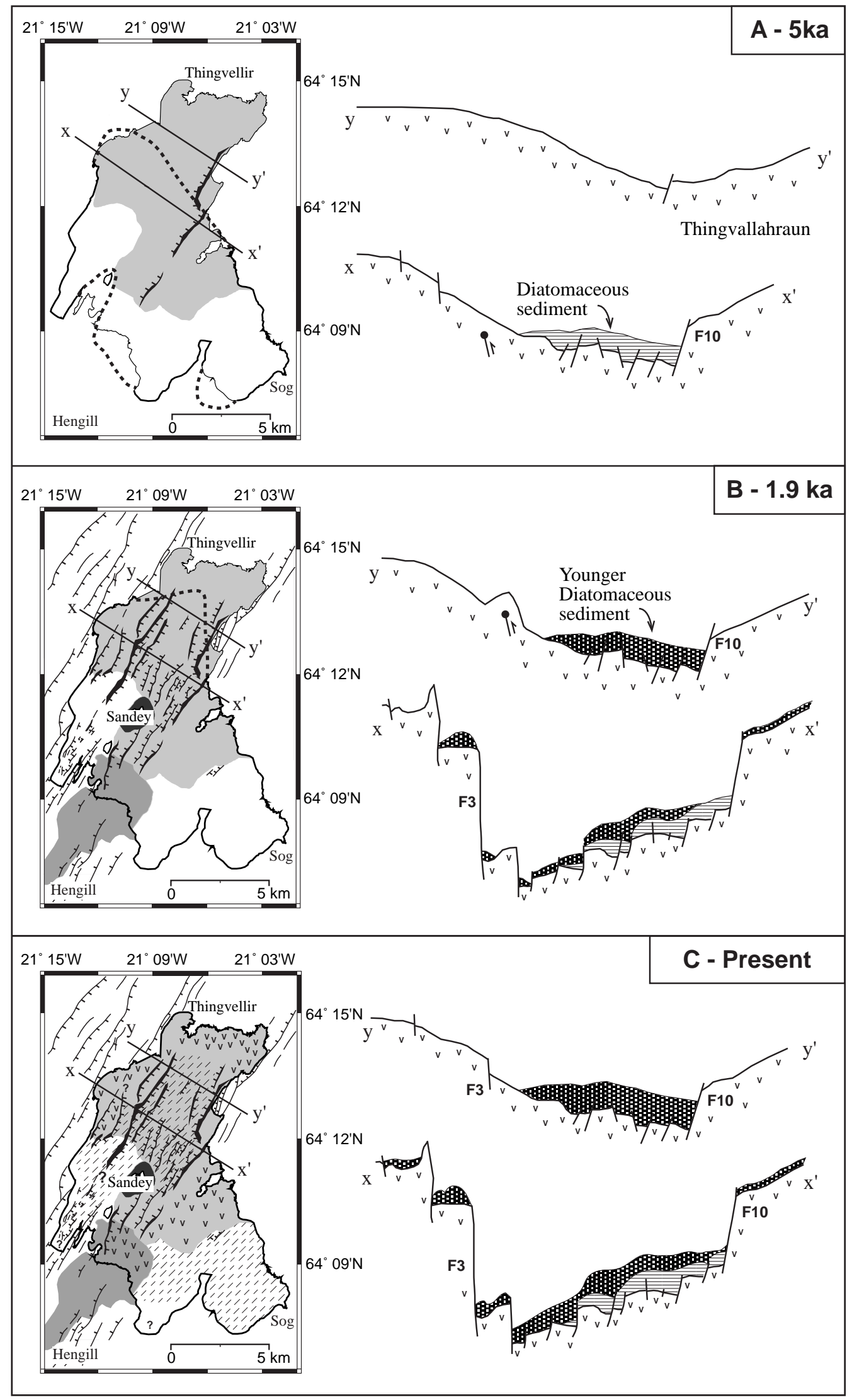

Figure 15. 